\title{
تصور مقترح من منظور خدمة الجماعة فى التعامل مع المشكلات التى تعانى منها المرأة المعنفة أسرياً
}

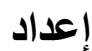 \\ الاكتورة// أمانى كمال عبدالله مصطفى \\ (مدرس خدمة الجماعة بالمعهز العالى للذدمة الإجتماعية بكفر صقر ـ شرقية)
}




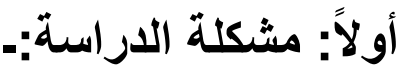

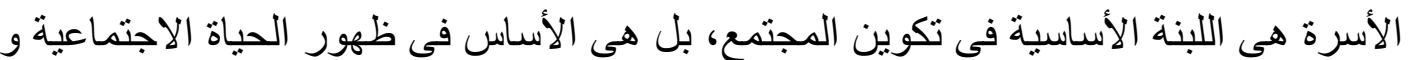

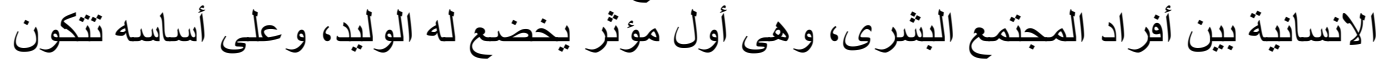

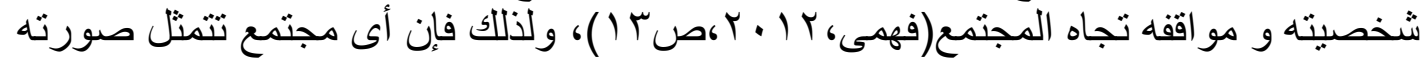

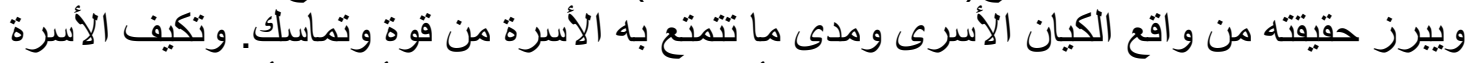

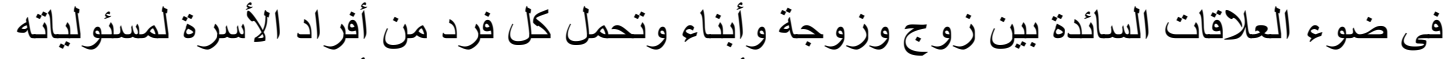

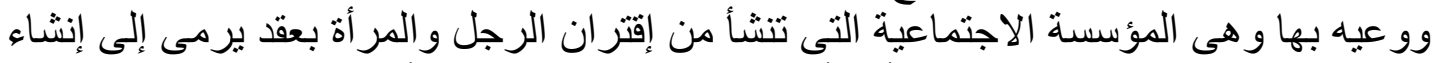

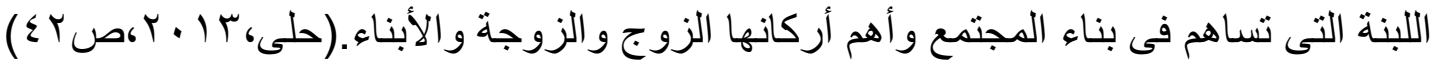

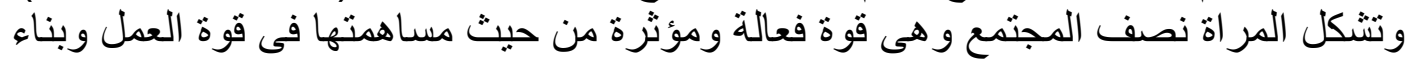

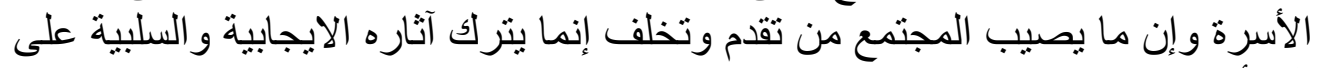

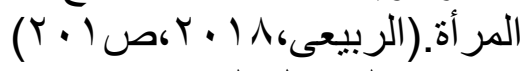

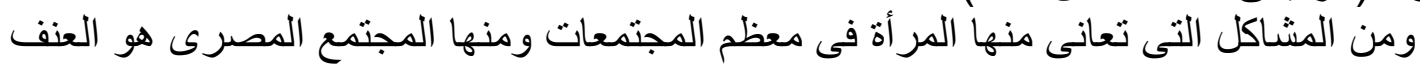

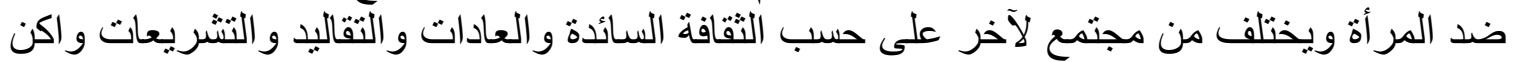

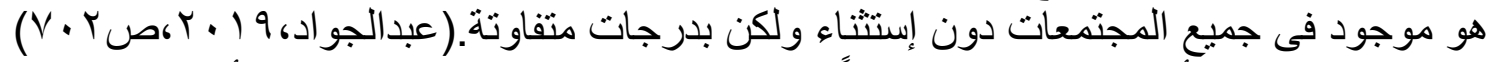

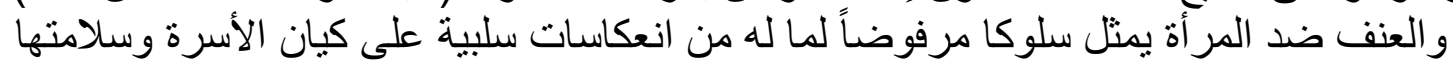

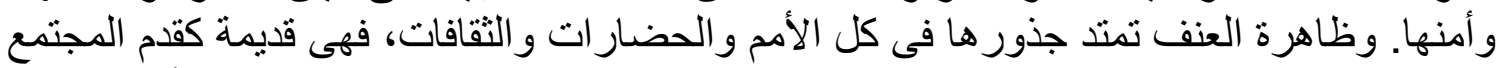

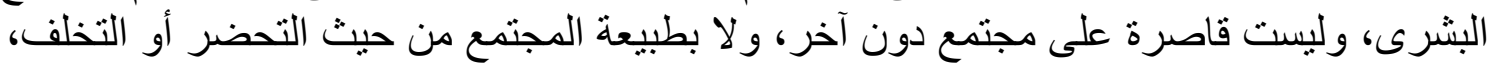

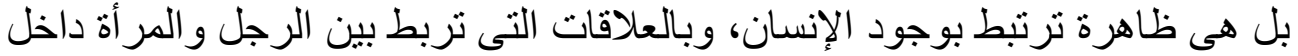

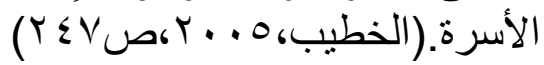

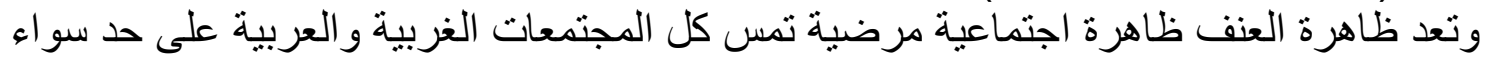

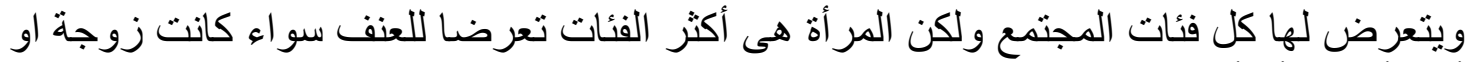

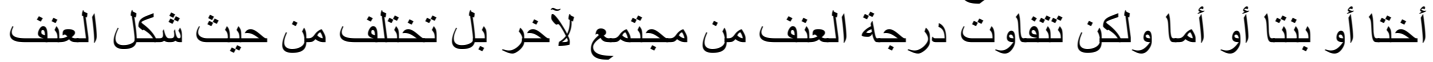

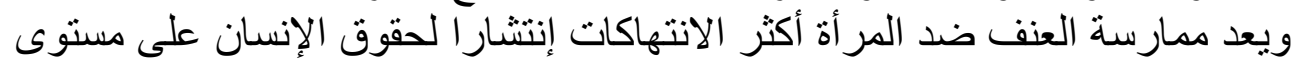

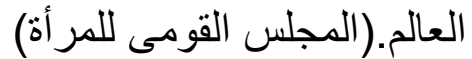

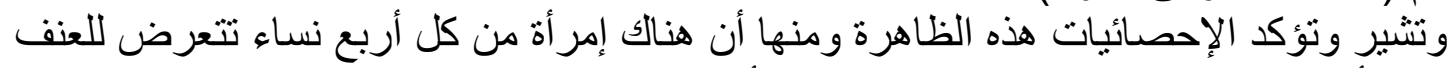

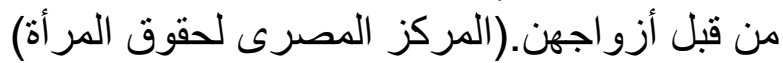

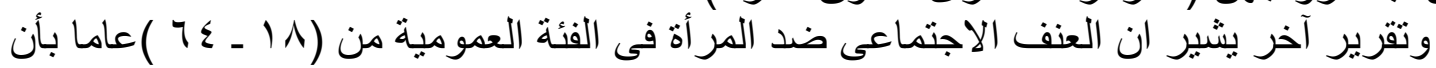

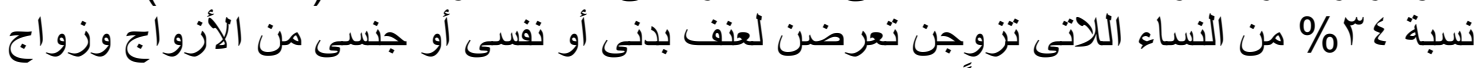

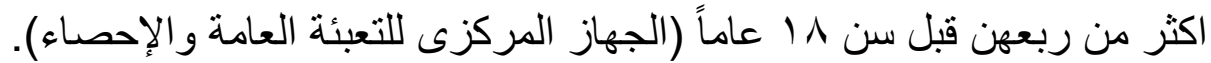

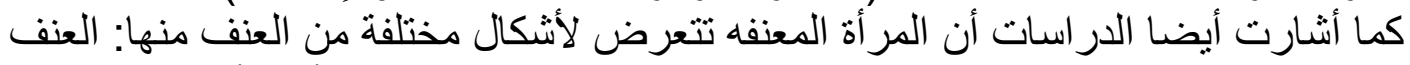

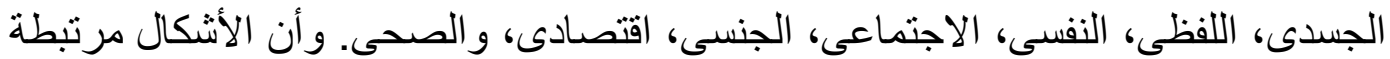

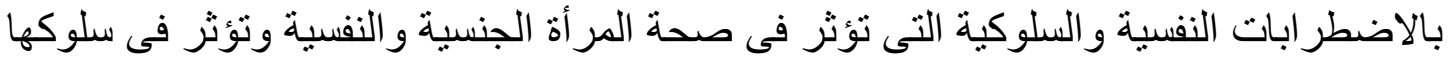

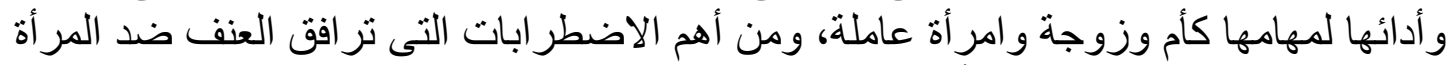

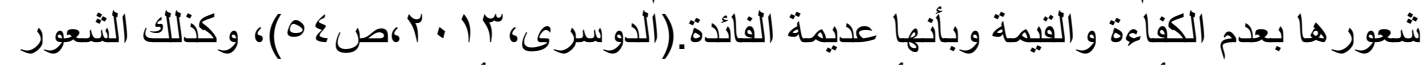

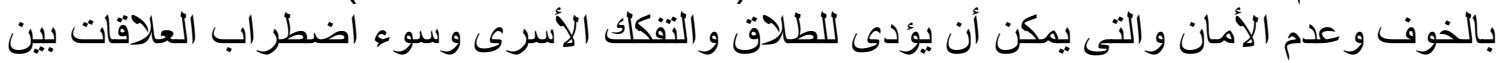

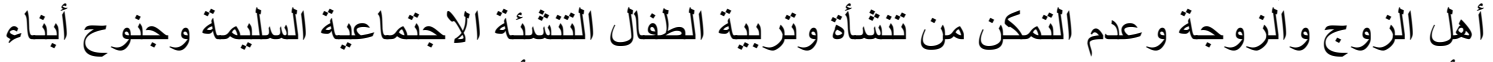
الأسرة التى فيها العنف و العدوان يصبح سائد بين جميع افر الد الأسرة

(Romito,2008,pp.155-176)

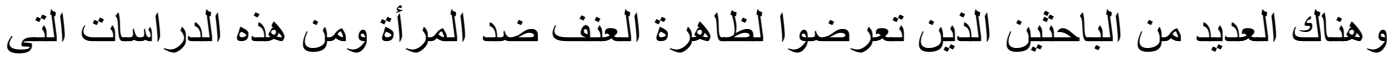

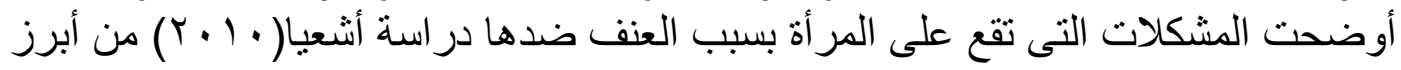


المشكلات التى تعانى منها المر أة المعنفة هى اضطر ابات انفعالية و الاحساس بانعدام معنى الحياة

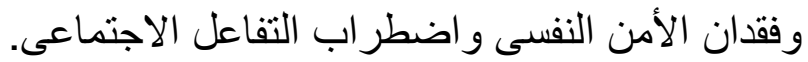

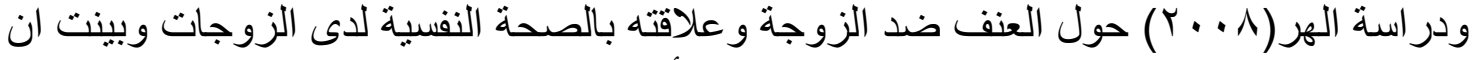

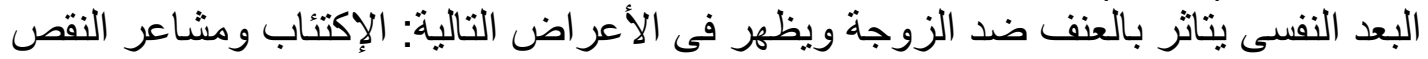

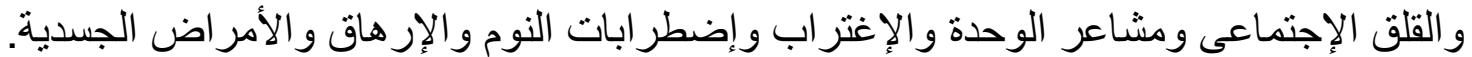

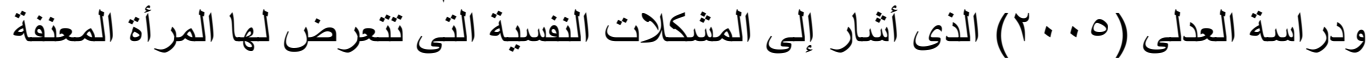

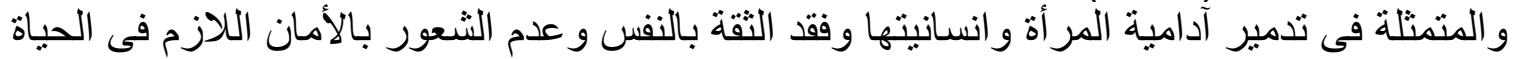

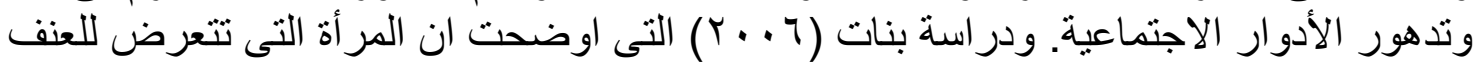

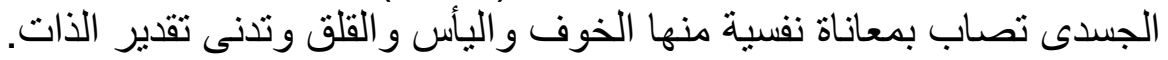

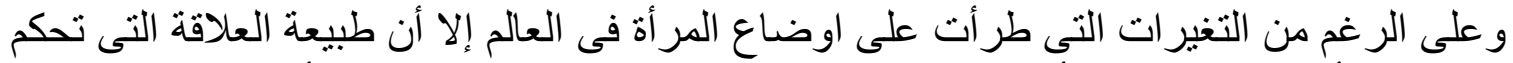

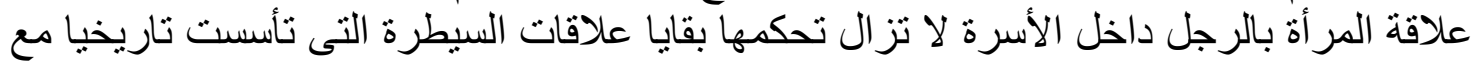

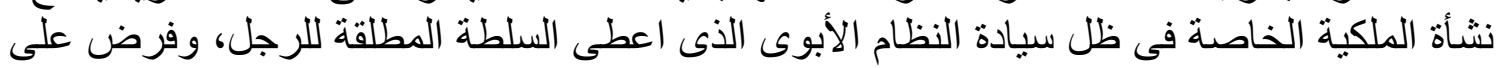

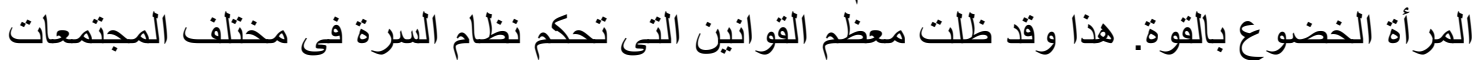

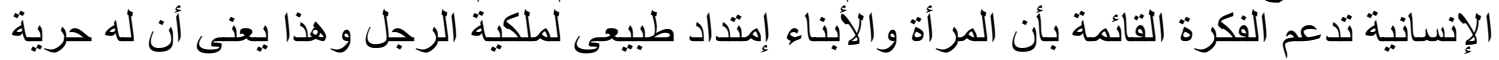

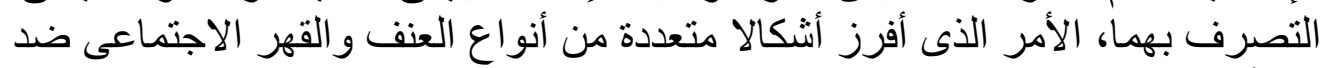

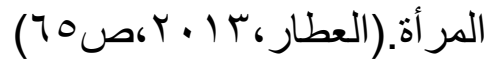

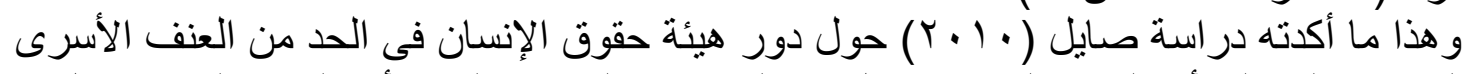

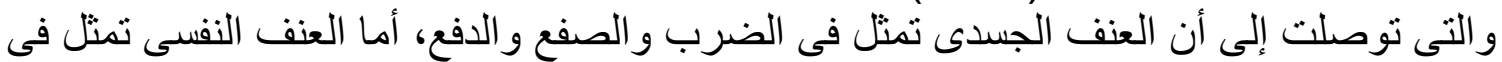

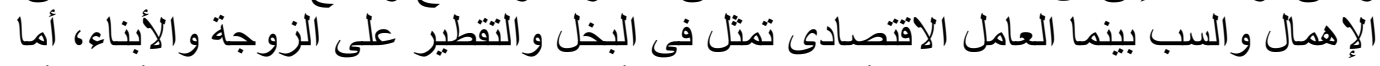

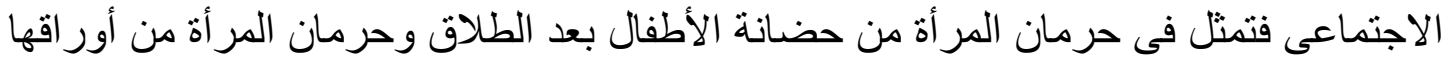

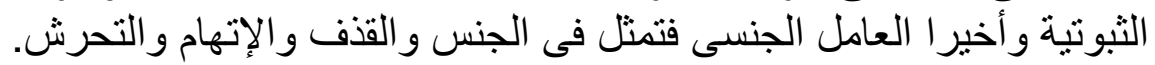

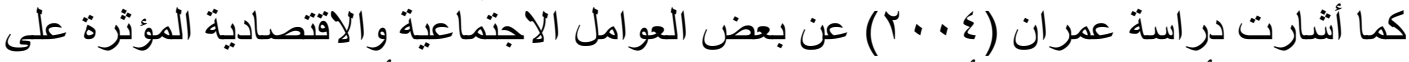

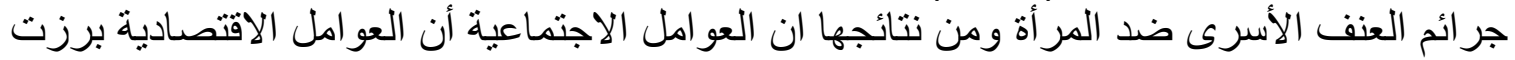

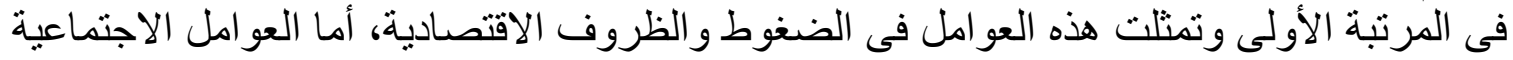

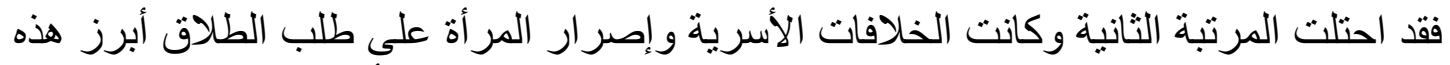

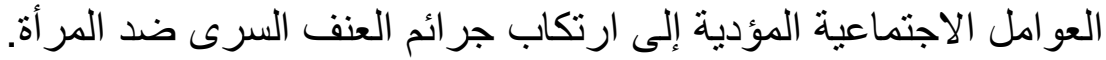

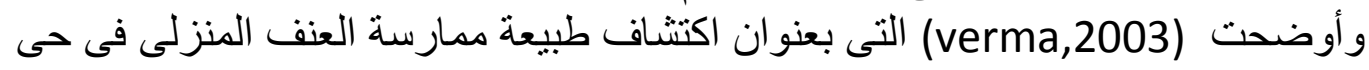

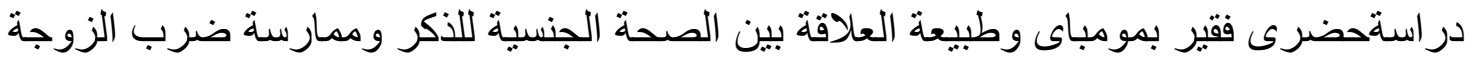

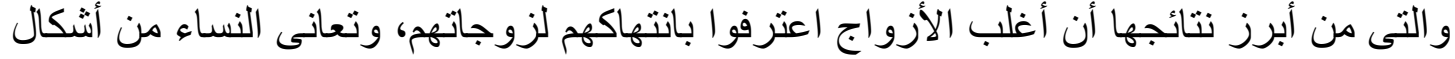

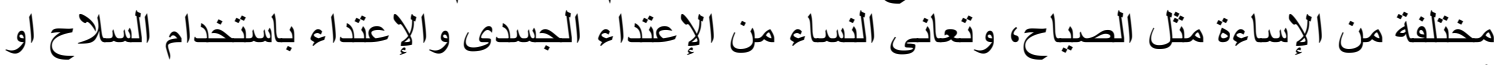

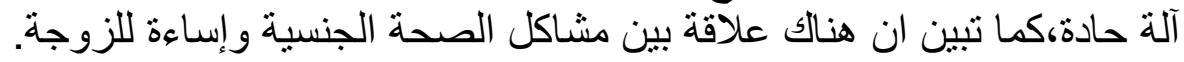

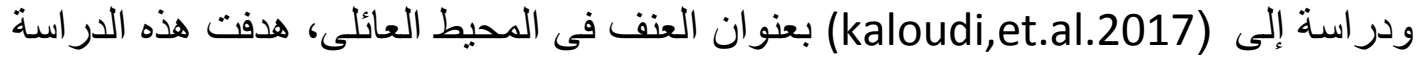

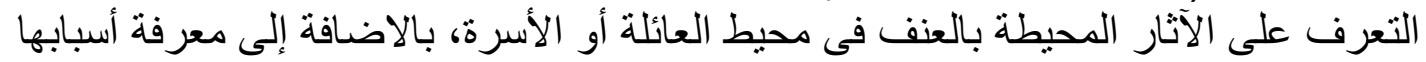

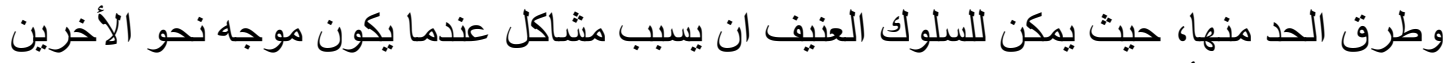

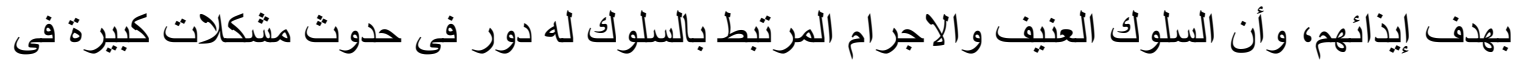
التماسك الاجتماعى و الصحة العامة.

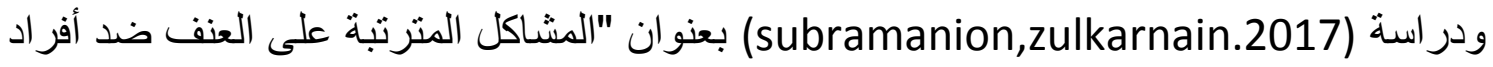

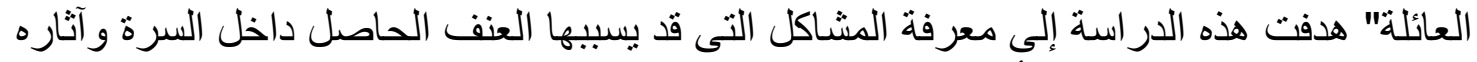

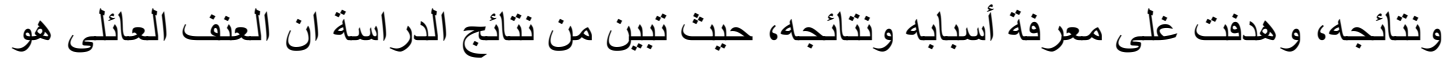




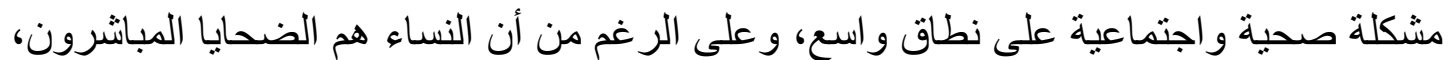

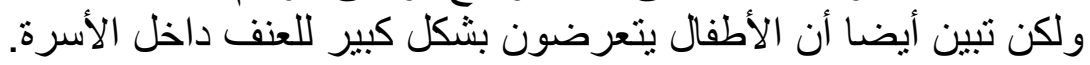

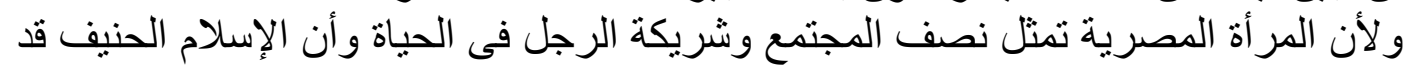

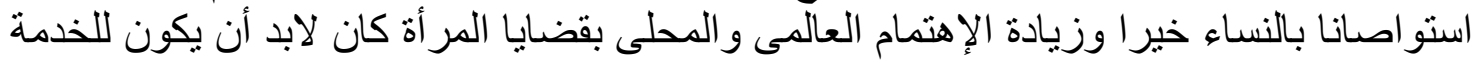

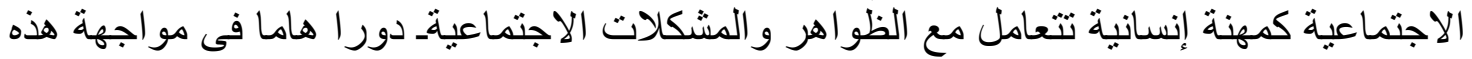

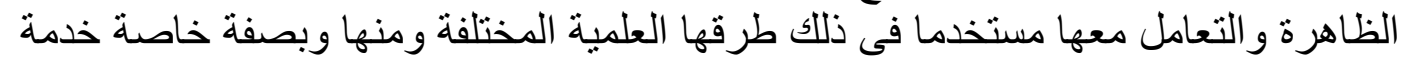

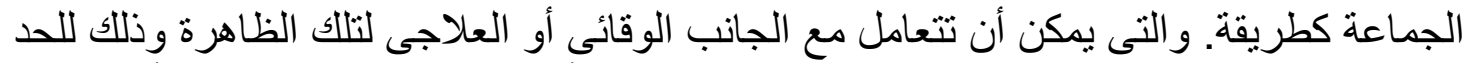

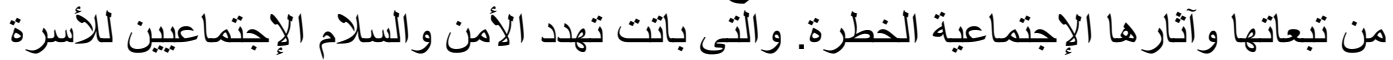

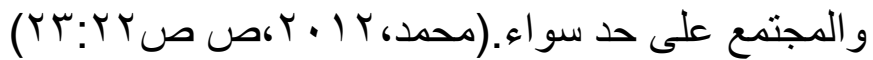

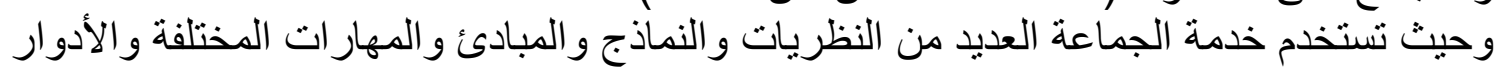

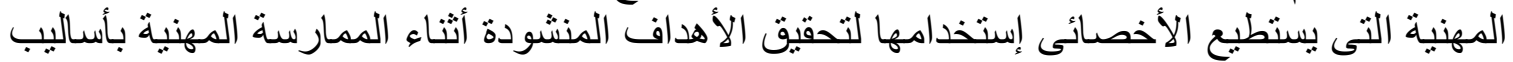

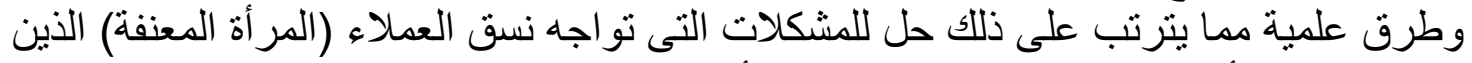

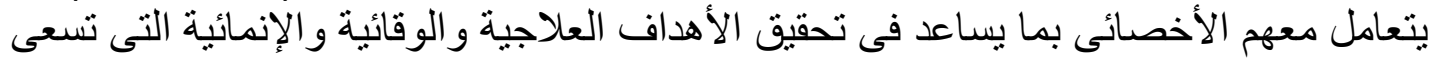

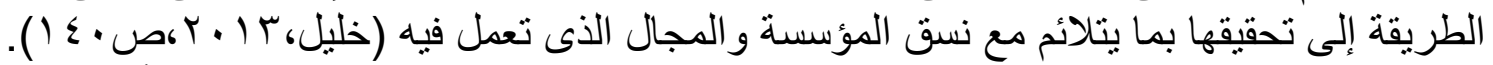

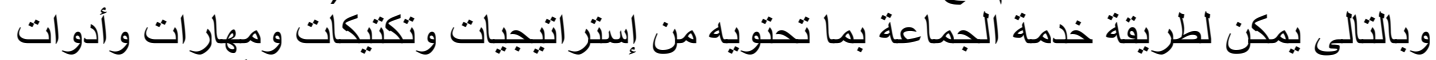

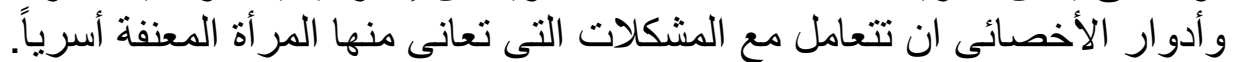

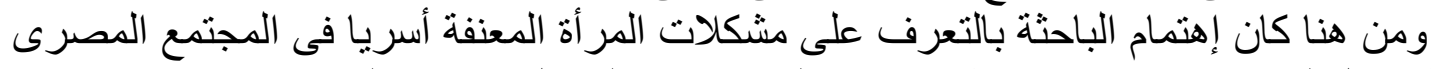

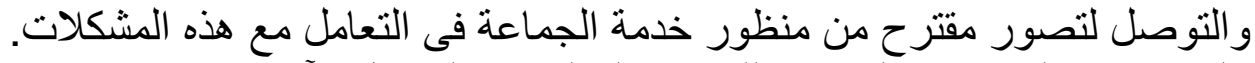
ولذا تحددت المشكلات الرئيسية للار اسة الحالية في التساؤل الآتى:

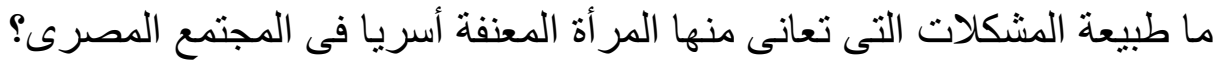

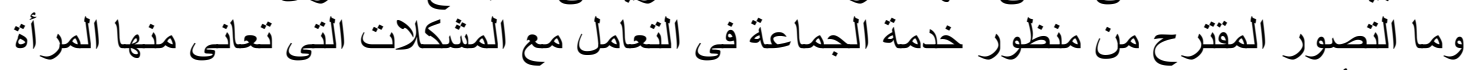

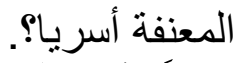

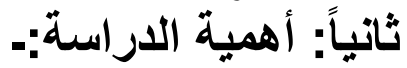
ا ـ زيادة أعداد النساء اللاتى يتعرضن للعنف الأسرى وتز ايد مناقتنته خلال وسائل الإعلام

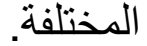

بـ الإهتمام العالمى و المحلى بقضايا المر أة مما يعود عليها و على المجتمع بالتقلم و الرقى.

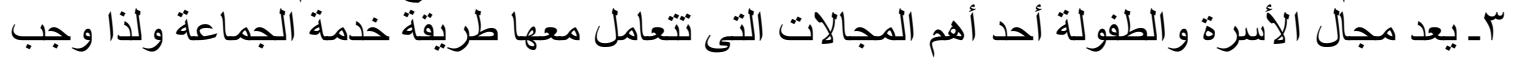

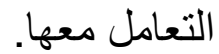
عـ محاولة رسم تصور و اضح لحل مشكلات العنف ضد المر أة مما ينعكس بالإيجاب على المجتمع

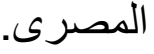

هـ كما تعد تللك الدر اسة وما يماثلها من دراسات علمية بمثابة فرصة سانحهة أمام مهنة الخدمة

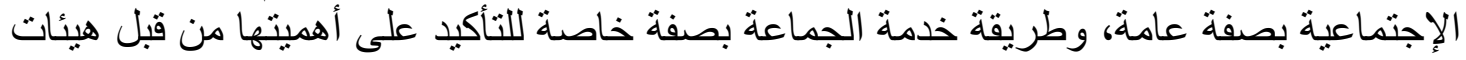

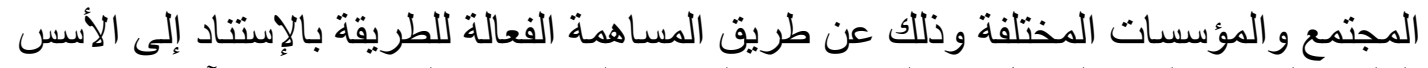

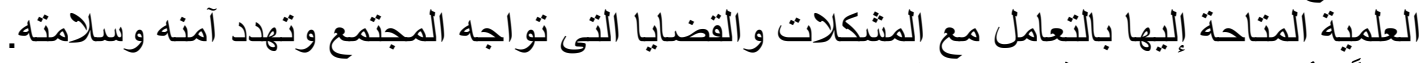

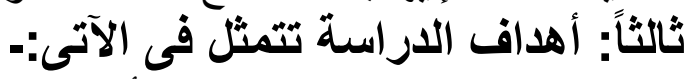

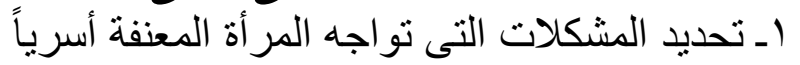

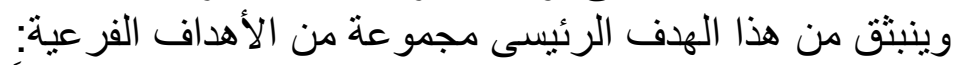

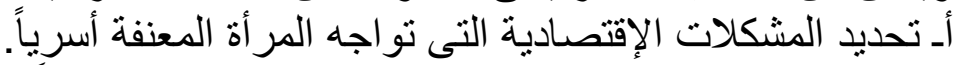

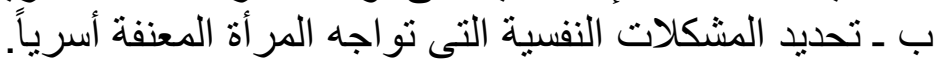


ج ـ تحديد المشكلات الإجتماعية التى تو اجه المر أة المعنفة أسرياً. دـ تحديد المشكلات الصحية التى تو اجه المر أة المئه المعنفة أسرياً. هـ ـ التوصل لتصور مقترح لطريقة خدمة الجمماعة فى التعامل مع المشكلات التهات التى تعانى منها المر أة المعنفة أسرياً.

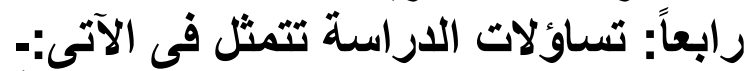

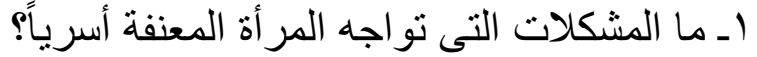

وينبثق من هذا التساؤل مجمو عة من التساؤلات التهات الفر عية :

أـ ما المشكلات الاقتصادية التى تو اجه المر أة المعنفة أسرياً ؟

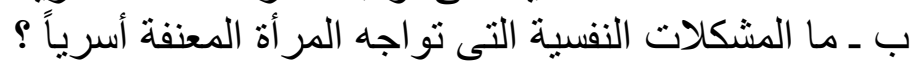

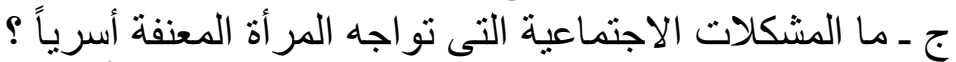

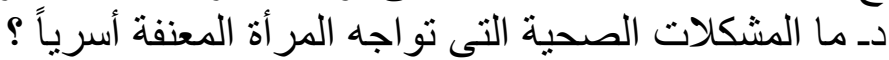

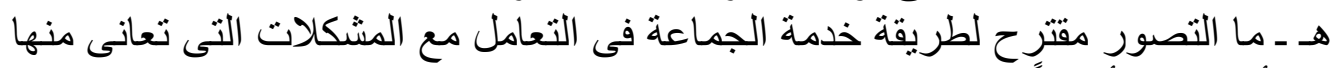

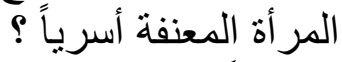
خامساً: الموجهات النظرية النظة للار استة:من أهم الموجهات النظرية التى تعتىد عليها الدراسة:

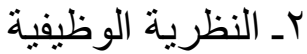
عـ النظرية النفسية الاجتماعية

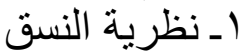
ــ ـ نظرية التنشئة الاجتماعية ـ أنظرية النسق:

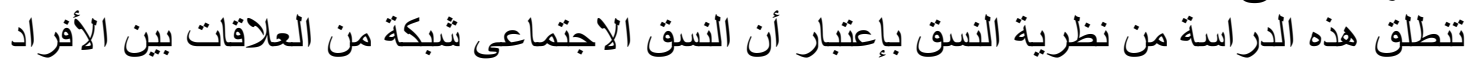

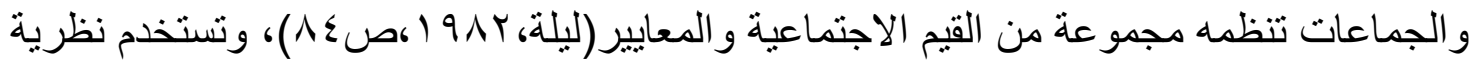

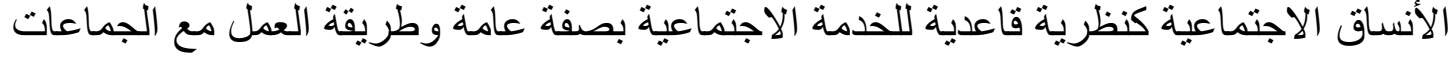

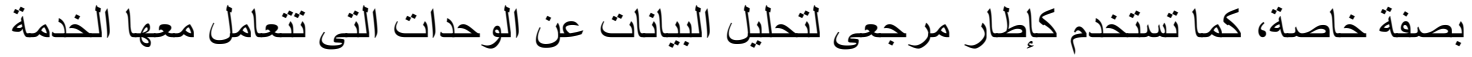

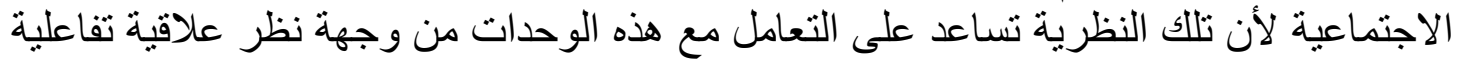

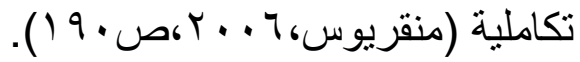

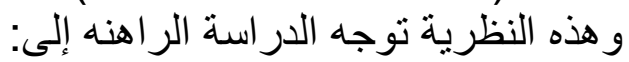

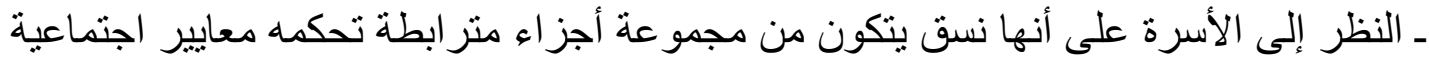
ومجموعة قيم أساسية تشكل عملية الضبط النبا بداخله. ـ لـذا النسق (الأسرة) احتياجات أساسية والتى تتمثل في توفير الأمن و الأمان و الاحتر ام لأعضائه

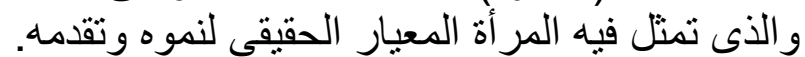

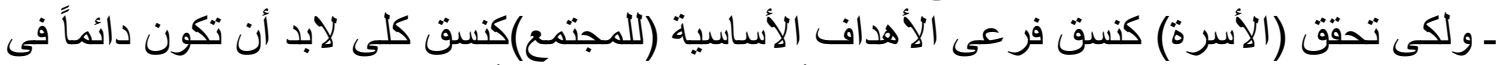

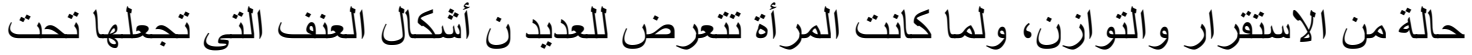

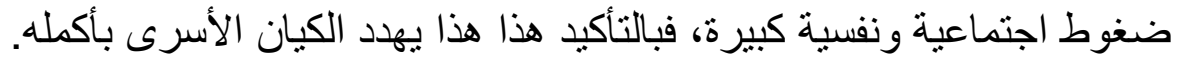

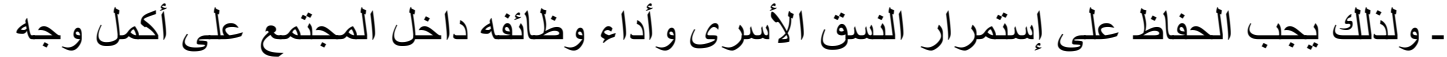

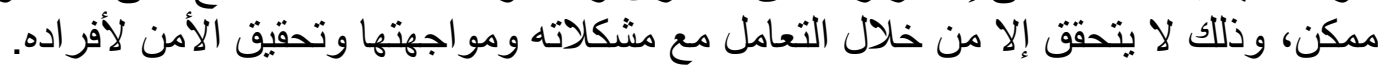

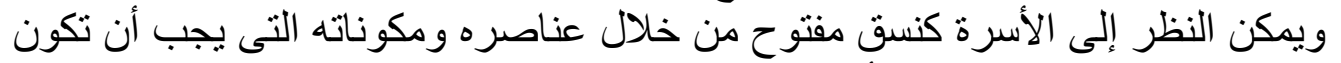

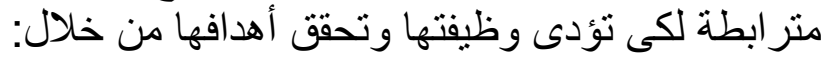

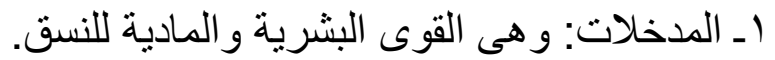

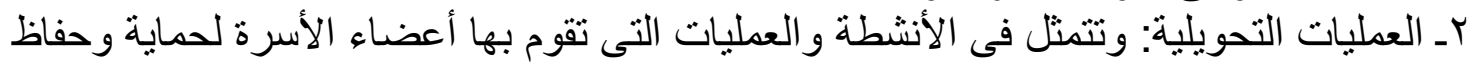

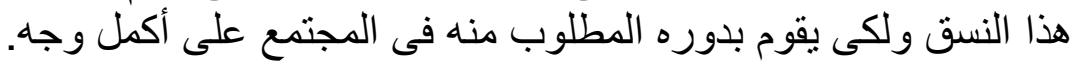


بـ المخرجات: وتشمل العائد النهائى والأهداف التى حققها النسق الأسرى و التى تشمل أداء وظائفه

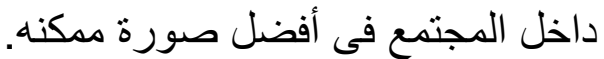

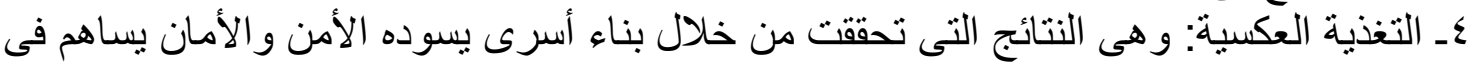
تقدم ورقى المجتمع ككل.

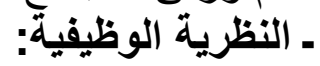

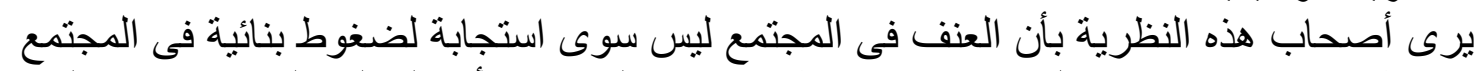

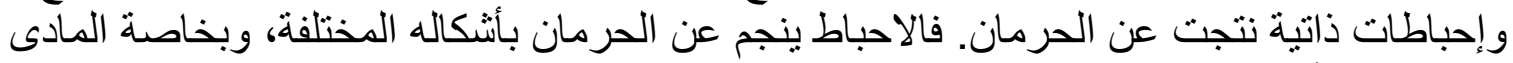

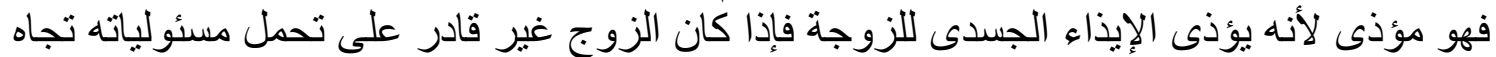

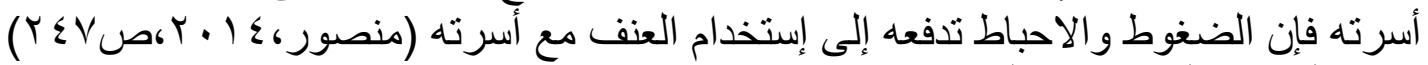
ـ نظرية التشثئة الاجتماعية:

تفترض مدرسة التنشئة الاجتماعية أن العنف يتعلم ويكتسب خلاعل عملية التنشئة الاجتماعية، كما

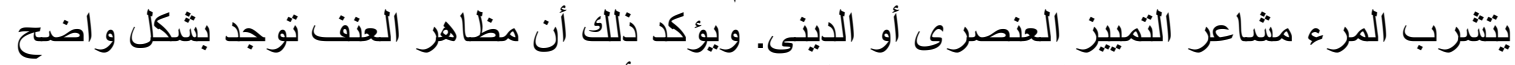

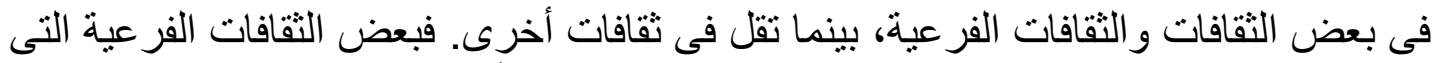

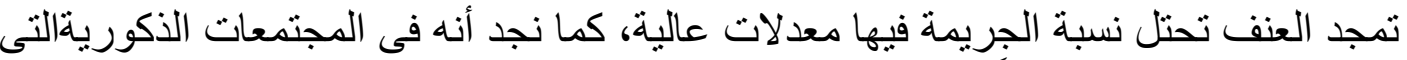

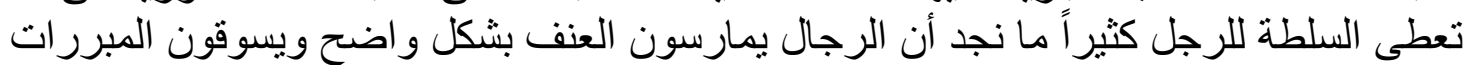

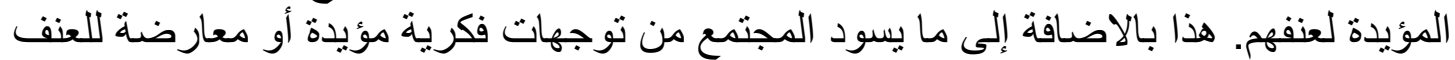

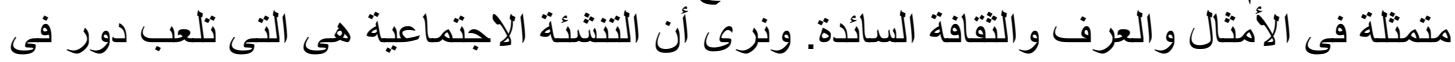

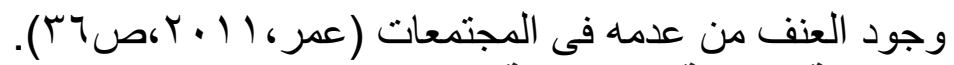
ـ النظرية النفسية الاجتماعية: يؤكد أصحاب هذه النظرية على أن الضغوطة الإنمية الاجتماعية لها دور بارز فى إرتكاب العنف وأن عدم توفرفرص الحياة والبطالة والفقر لها دورفى تشكيل الضغوط على على الفرد مها يقوى احتمالية

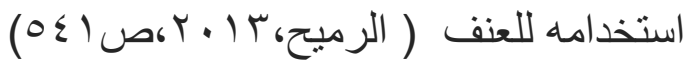

\section{سادساً: مفاهيم الاراسة:}

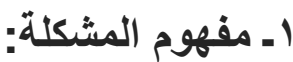

تعرف المشكلة لغويا على أنها " التباس الأمر" ،لأن معنى كلمة التباس الأمرأى أشكل عليه

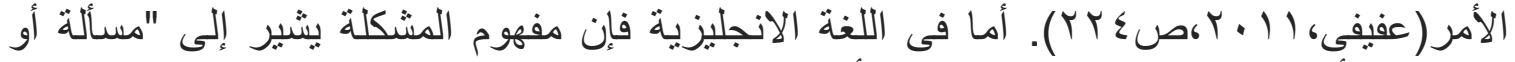

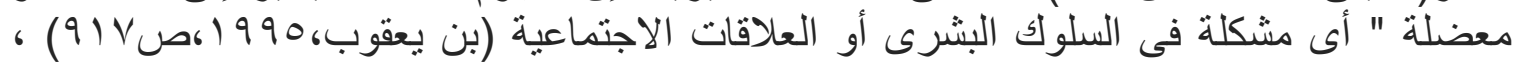

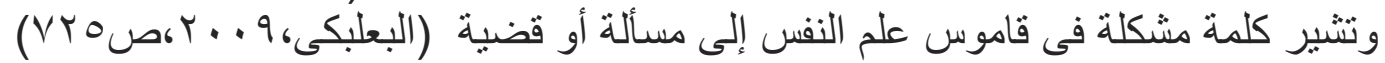
وتعنى كلمة مشكلة فى معجم العلوم الإجتماعية ظاهرة تتكون من عدة أحداث ووقائع منشابهة

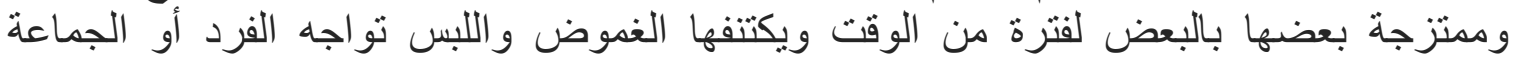
ويصعب حلها قبل معرفة أسبابها و الظروف المحيطة بها وتحليلها للوصول إلى اتخاذ قرار بشأنها

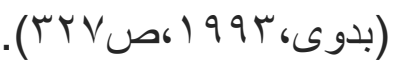
كما تعرف المشكلة بأنها إنحراف السلوك الاجتماعي عن القواعد الته التى حددها المجتمع للسلوك

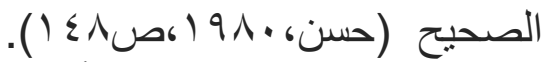
وتعرف المشكلة الاجتماعية بأنها وضع إجتماعي غير مرغو غوب فيه ويحتاج إلى جذب الانتباه إلباه إلبه

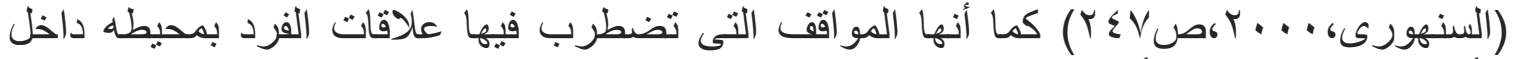

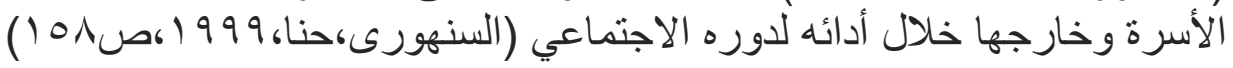


والباحثّه تقصد بالمشكثة فى هذه الدراسة ما يلى:

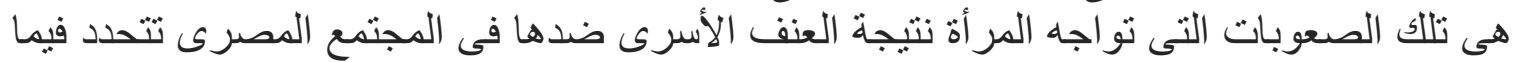
ا ـ المشكلات الاقتصادية التى تو اجه المر أة المعنفة أسريا.

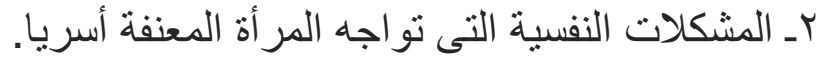

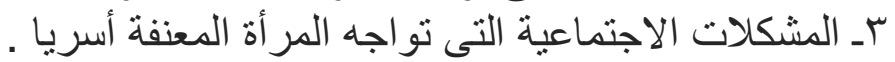

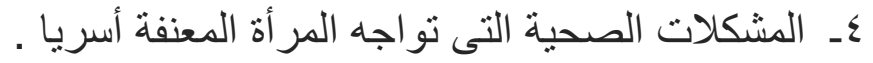

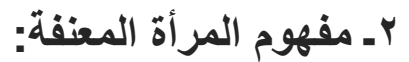

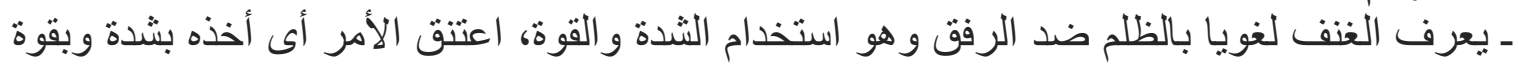

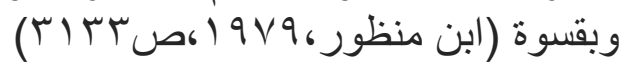

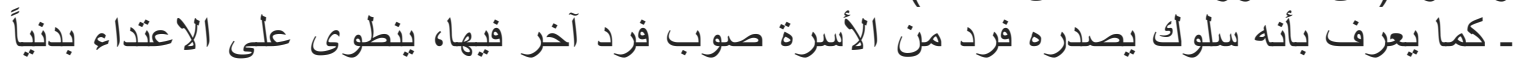

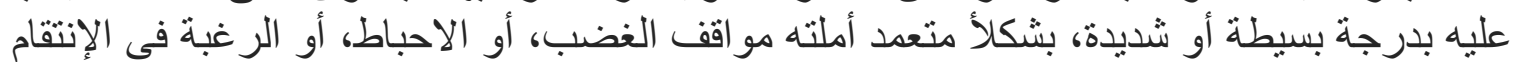

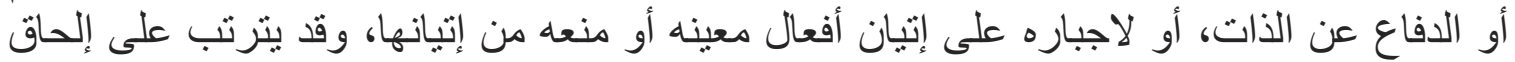

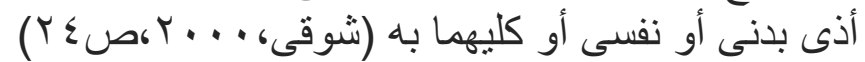

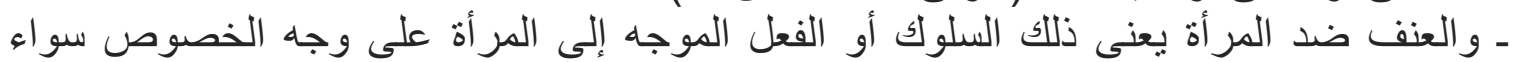

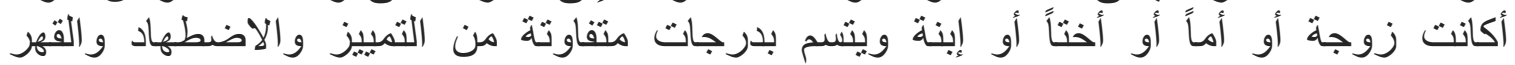

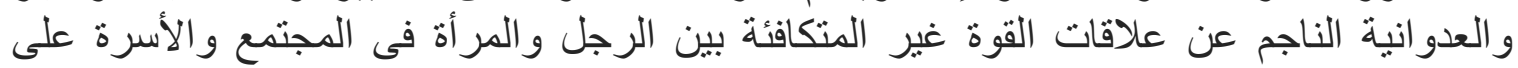

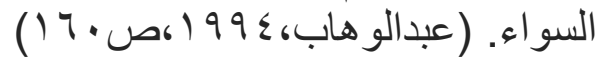

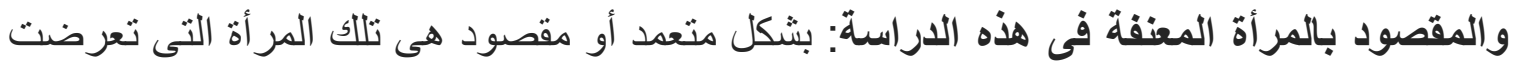

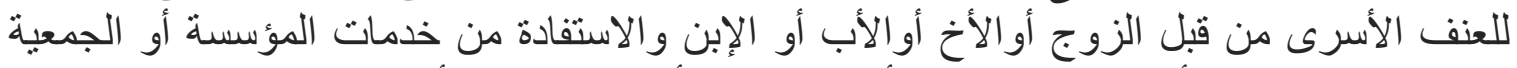

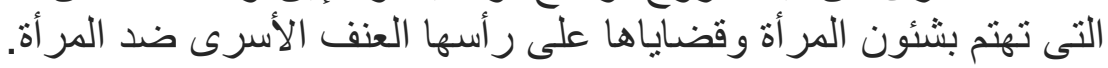

ب ـ مفهوم العنف ضد المرأة: هو أى فعل عنيف قائم على أساس الجنس، ينجم عن أذى أو أو معاناة جسدية أو جنسية أو نفسية

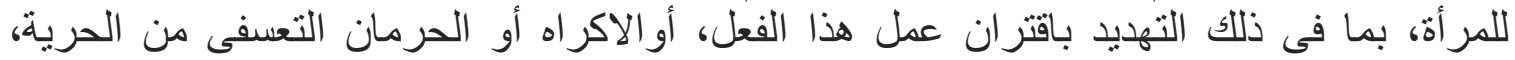

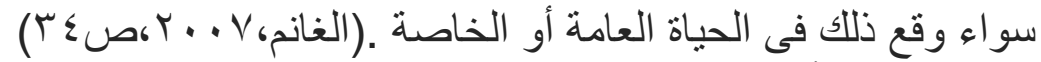

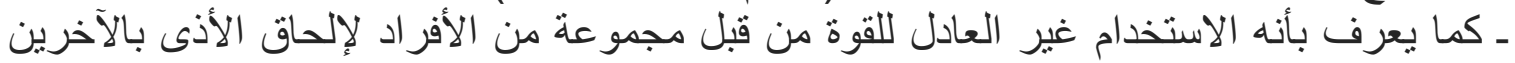
و الإضر ار بمنانكاتهم. Rivera\& Switzer,1976,p.35 )

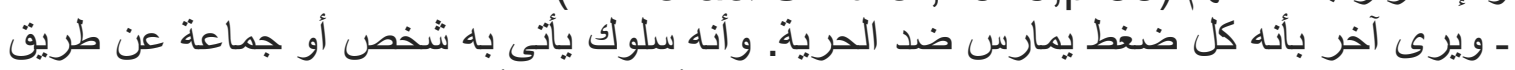

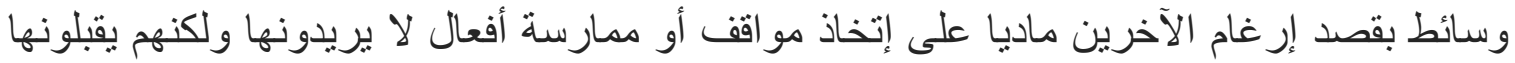

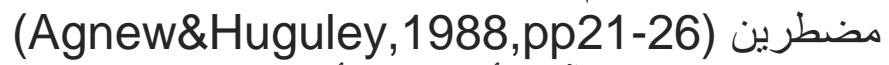

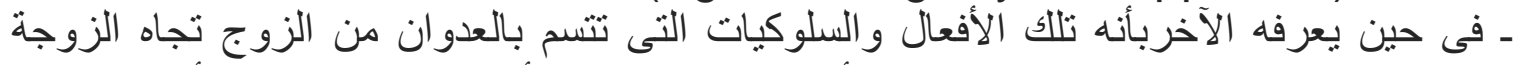

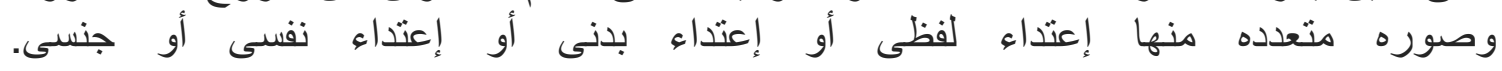

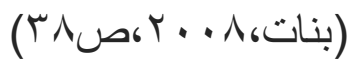


ـ و ويشار إلى أن العنف الأسرى ضد المرأة يمكن أن يشمل الحرمان الإقتصادى والعزلة وأن مثل

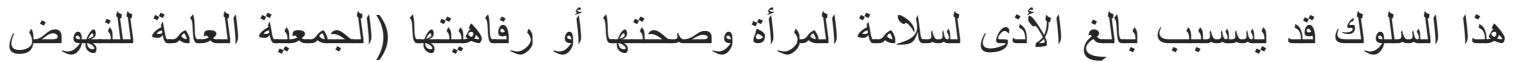

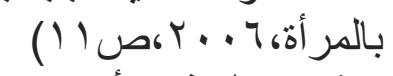
ويقصد بالعنف الأسرى ضد المد المرأة فى هذه الاراسة:

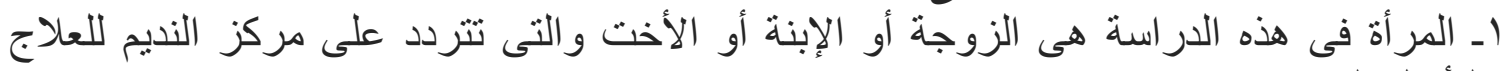
و التأهيل النفسي.

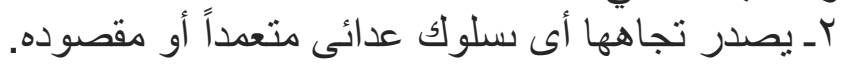

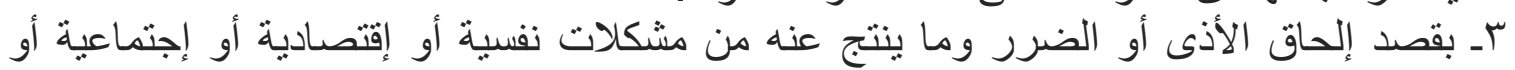
صحية. عـ يكون لها شكوى بأنه واقع عليهاأى أشكال العنف من قبل الأسرة.

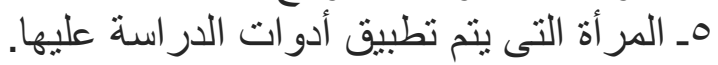

\section{سابعاً: الإجراءات المنهجية للاراسة:}

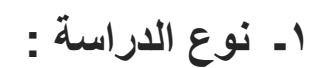

تعتبر الدر اسة من الدراسات الوصفية لأنها أنسب أنواع الدراسات لدراسة الحقائق المتعلقة بطبيعة

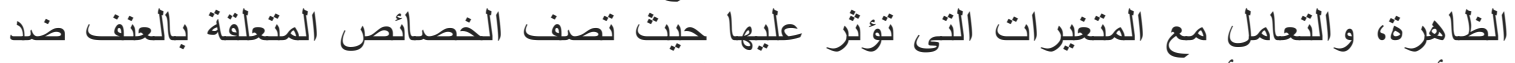
المر أة من حيث الأسباب و الدو افع و النتائج المترتبة على على ذلك.

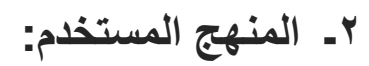

وقد إستخدمت الباحثة منهج البحث الإجتماعى بأسلوب الحصر الثنامل للنساء المعنفات بإعتبارها المنهج المناسب للار اسة الوصفية.

ץـ أدوات الدراسة: حددت الباحة أدوات دراستها فى الآتى:-

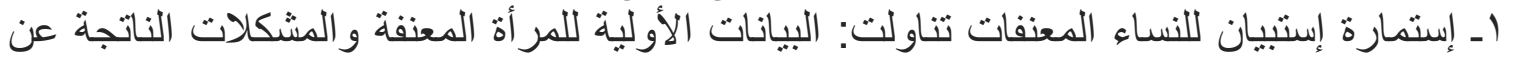

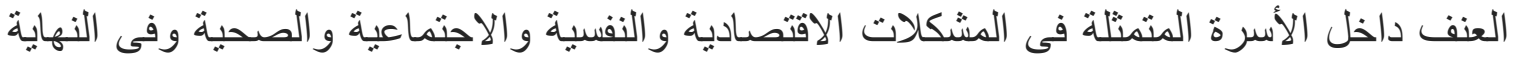
مقترحات للتعامل مع تلك الكن المشكلات.

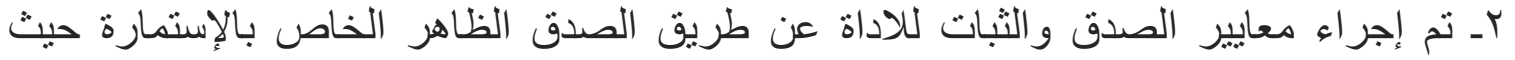
استخدمت الباحثة صدق المحكمين، وذللك بعرض إستمارة الاستبيان على عدد (10) من المان المحكين 


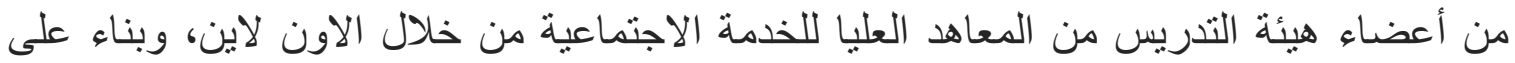

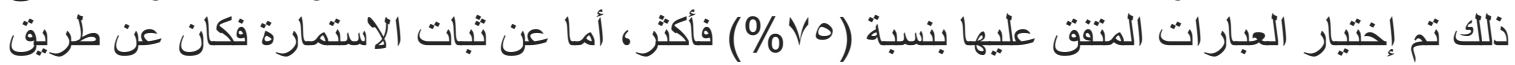

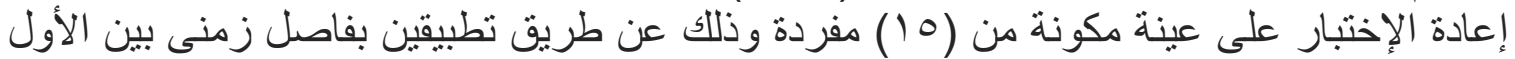

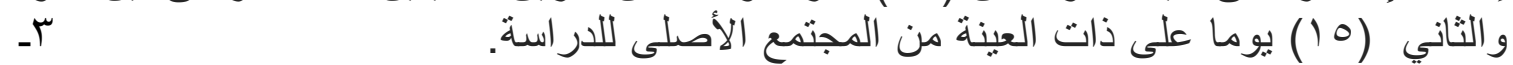

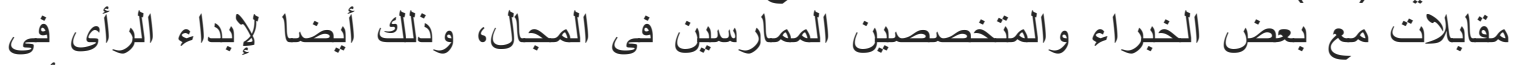

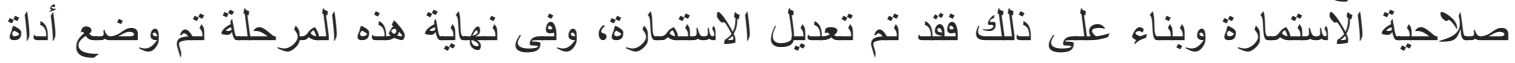
الدر اسة فى صورتها النهائية.

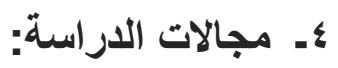

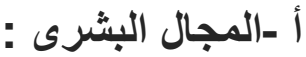

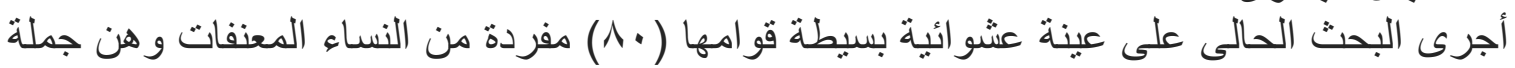

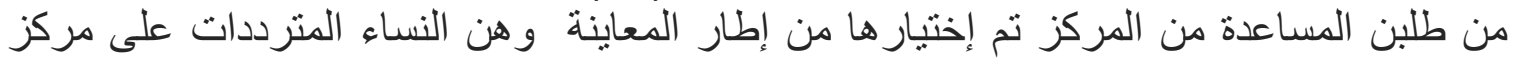

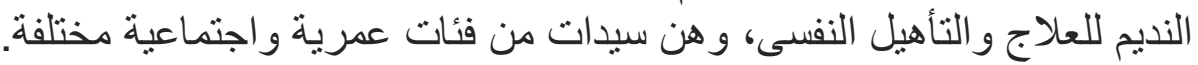

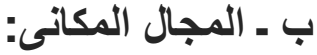
أجرت الباحثه الدراسة الحالية فى مركز النديم للعلاج و التأهيل النفسى بسليمان الحلبى ـ رمسيس القاهرة .وتم إختيار المجال المكان المبرة المبررات الآتية:

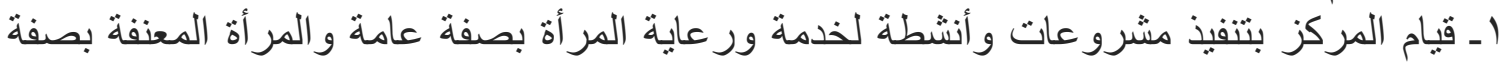
خاصة.

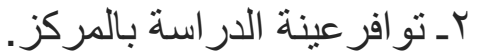

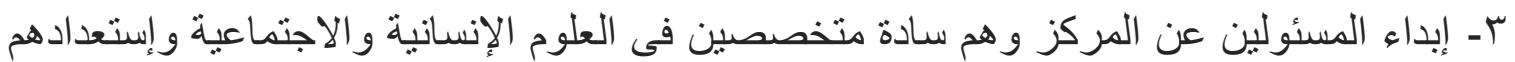

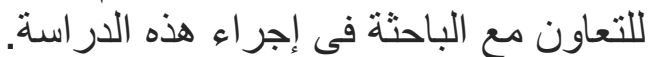
عـ وقوع المركز فى منطقة يكثر بها لهن المشكلات الاجتماعية والتى يمكن أن تؤثر على الأسر بها

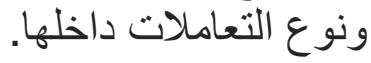

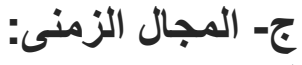

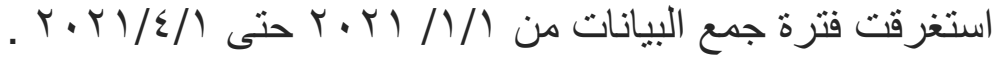




\section{نتائج الاراسة}

جدول رقم (1)

$\Lambda \cdot=\dot{0}$

يوضتح وصف مجتمع الدراسة

الحالة التعليمية ن

الإقامة

السن

الهنغيز 


\begin{tabular}{|c|c|c|c|c|c|c|c|c|c|c|c|c|c|}
\hline 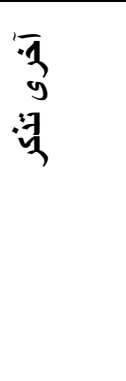 & $\begin{array}{l}3 \\
3 \\
\frac{9}{3}\end{array}$ & $\begin{array}{l}3 \\
3 \\
3 \\
3 \\
3\end{array}$ & 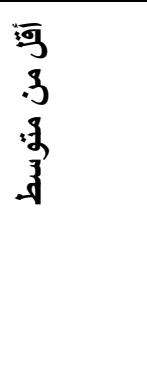 & $\overline{9}$ & $\begin{array}{l}\sqrt{3} \\
\text { y } \\
\text { 势 }\end{array}$ & $\begin{array}{l}\frac{3}{3} \\
\frac{3}{3}\end{array}$ & 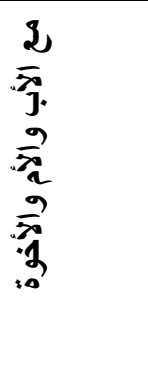 & 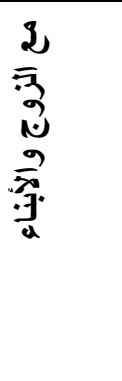 & 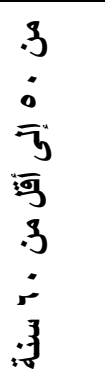 & $\begin{array}{l}.3 \\
\vdots \\
\overline{3} \\
\text { iag } \\
.3 \\
\vdots \\
\vdots \\
: 3\end{array}$ & $\begin{array}{l}3 \\
3 \\
2 \\
\overline{3} \\
: 53 \\
.3 \\
\vdots \\
\vdots \\
.3\end{array}$ & 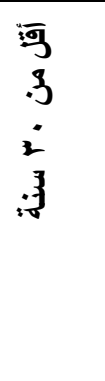 & التقلير \\
\hline 0 & ro & Yo & 10 & 1. & 1. & 10 & ro & $r$. & $r$. & $r$. & 1. & $r$. & ك \\
\hline $\begin{array}{r}\text { r. } \\
\%\end{array}$ & $\%^{r}-r_{0}$ & $\%$ \% & $\%$ '^.৩० & $\%$ 'ч.० & $\begin{array}{r}1 Y .0 \\
\%\end{array}$ & $\%$ \%४.० & $\%^{\mu}-r_{0}$ & $\begin{array}{r}r v_{.}{ }^{\circ} \\
\%\end{array}$ & $\%$ Yo & $\begin{array}{r}r v_{.}^{\circ} \\
\%\end{array}$ & $\begin{array}{r}1 Y .0 \\
\%\end{array}$ & $\%$ ro & النسبة \\
\hline
\end{tabular}

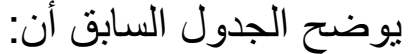

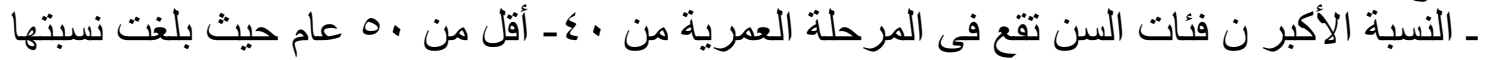

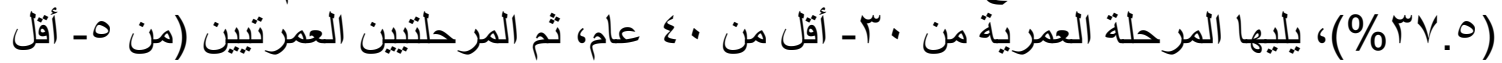

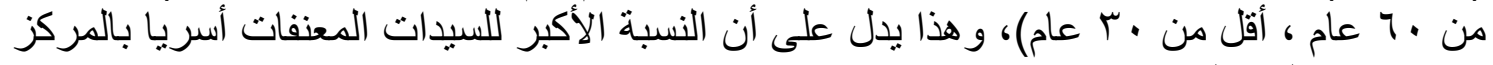

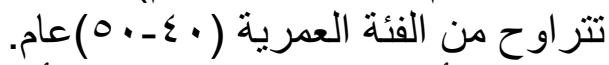

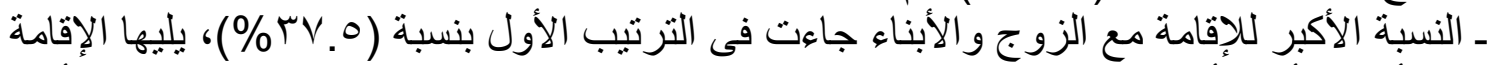

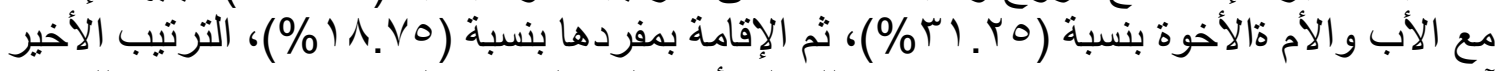

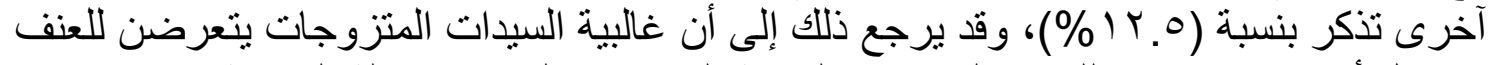

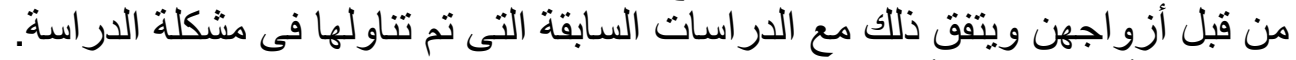

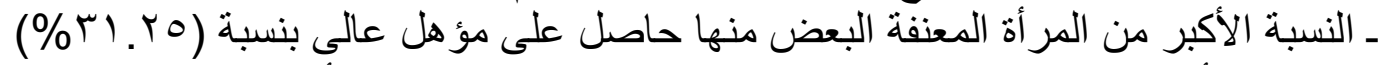

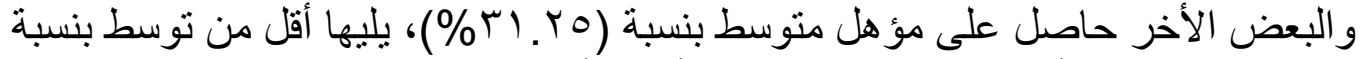

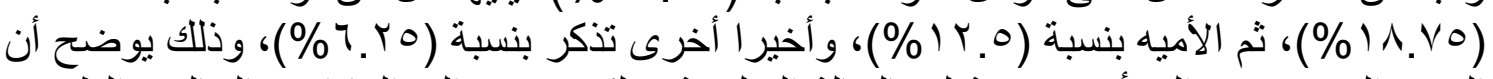

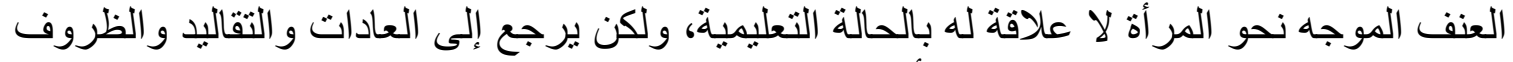
الاجتماعية والاقتصادية التى تعيشها الأسرة.

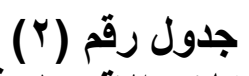

يوضح المشكلات الإقتصادية للنساء المعنفات أسريا

\begin{tabular}{|c|c|c|c|c|}
\hline الترتيب & النسبة & التكرار & العبارة & م \\
\hline$r$ & $\% \vee 0$ & \%. & يحاسبنى على صرفى للمال & 1 \\
\hline r & $\% \wedge 1$. Yo $^{\circ}$ & 10 & يرفض منحى ما يكفى من المال لإثباع احتياجاتتا الأسرية & r \\
\hline 1 & $\%$ \%ฯ.V० & vo & غير تعاون فى تدبير نفقات معيشتا & $r$ \\
\hline
\end{tabular}




\begin{tabular}{|c|c|c|c|c|}
\hline 0 & $\%$ \%r.0 & o. & يأخذ أموالى التى من أهلى ويصرفها على نفسه فقط & $\varepsilon$ \\
\hline $\mathrm{V}$ & $\% 0$. & $\varepsilon$ & يبيع من أثثاث المنزل ليصرف على البيت & 0 \\
\hline 7 & $\% 07 . Y 0$ & $\leqslant 0$ & يأخذ أملاكى الخاصة ويتصرف بها دون إذنى & 7 \\
\hline 9 & $\% r v .0$ & $r$. & يضطرنى للاستدانه لسد احتياجات الأسرة & $\mathrm{V}$ \\
\hline$\varepsilon$ & $\% \curlyvee \wedge . \vee 0$ & 00 & يتحكم زوجى فى جميع المصروفات ويهمل بعض مطالب الأسرة & $\Lambda$ \\
\hline$\Lambda$ & $\% \leqslant r . \vee 0$ & ro & يقوم بتببلد مدخرات الأسرة & 9 \\
\hline
\end{tabular}

يوضنح الجدول السابق:

المشكلات الإقتصادية للنساء المعنفات أسريا تتمثل بالترتيب كالأتى: فى الترتيب الأول غير

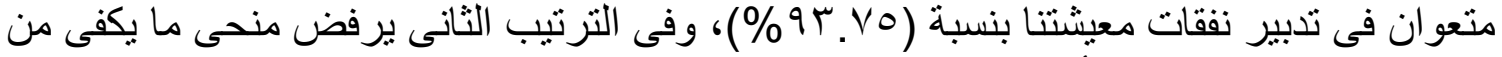

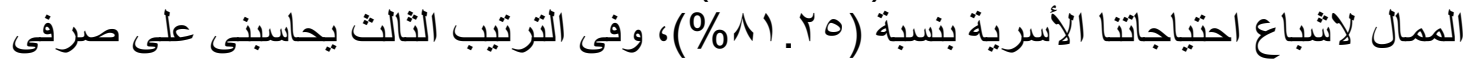

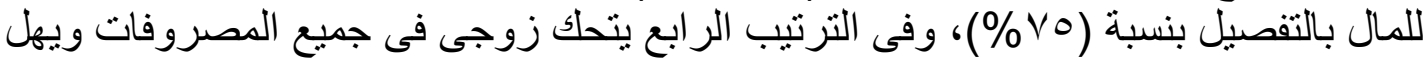

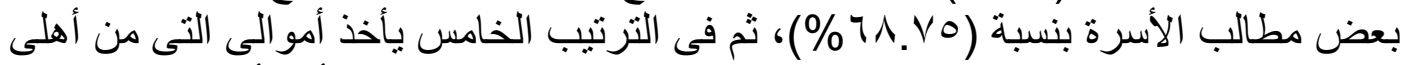

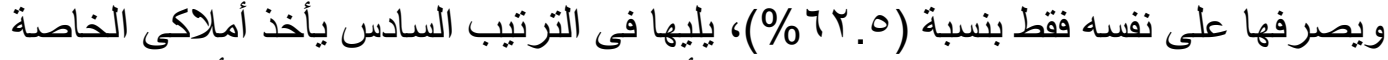

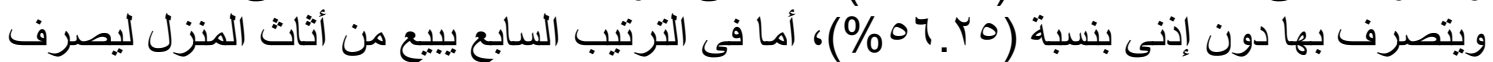

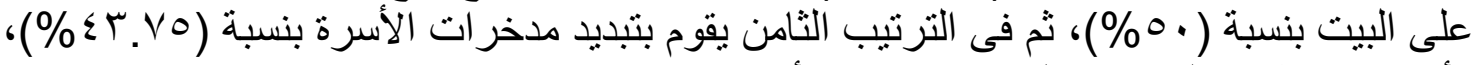

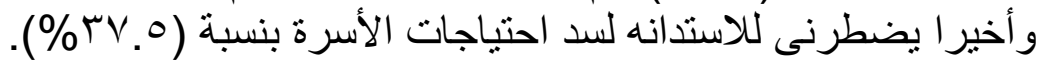

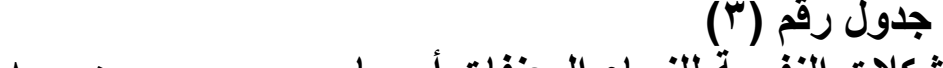

يوضتح المشكلات النفسية للنساء المعنفات أسريا

\begin{tabular}{|c|c|c|c|c|}
\hline الترتيب & النسبة & التكرار & العبارة & r \\
\hline$r$ & $\%$ \%. & $\mathrm{V} \cdot$ & أشعر بعدم الأهمية وقلة احترام الأخرين لى & 1 \\
\hline $\mathrm{V}$ & $\% \circ$. & $\varepsilon$. & أعانى من السخرية من تصرفاتى والتقليل من أهميتى & r \\
\hline 7 & $\%$ \%r.0 & o. & أشعر بالخوف والقلق لتركى وحيده بالمنزل طول الوقت & $r$ \\
\hline$\varepsilon$ & $\% \vee 0$ & 7. & أجد صعوبه فى الإحساس بالأمان نتيجة ممارسة العنف تجاهى & $\varepsilon$ \\
\hline$\Lambda$ & $\% r v .0$ & $r \cdot$ & أعانى من الإحباط وعدم وجود هدف فى حياتى & 0 \\
\hline 0 & $\% \curlyvee \wedge . \vee \bullet$ & 00 & يرهقتى إحساسى بالتجاهل فى الحياة الأسرية & 7 \\
\hline r & $\% \wedge 1 . Y 0$ & 70 & قلة التكيف مع زوجى نتيجة ممارسة العنف معى & $\mathrm{V}$ \\
\hline
\end{tabular}




\begin{tabular}{|c|c|c|c|c|}
\hline 1 & $\% 9 r . v 0$ & Vo & زوجى دائما فى مستقبل أبنائى بسبب سوء العلاقةّة بينى وبين & $\Lambda$ \\
\hline$\varepsilon$ & $\% \vee 0$ & 7. & أشُعر بالظلم لعدم أخذ رأيى فى شئون المنزل & 9 \\
\hline
\end{tabular}

يوضح الجدول السابق أن:

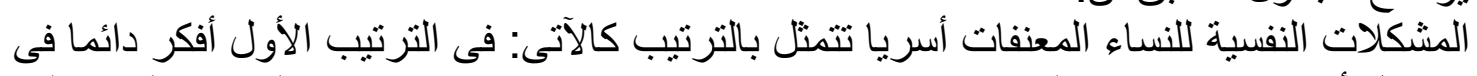

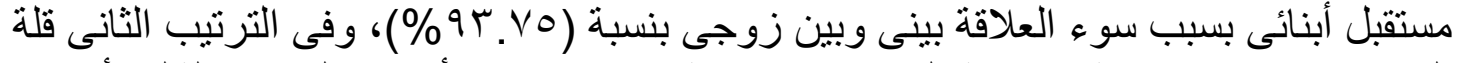

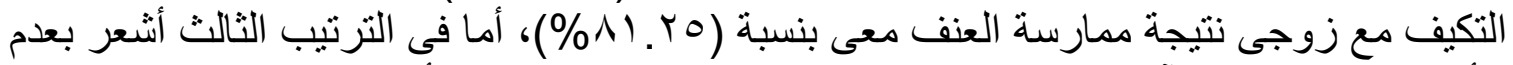

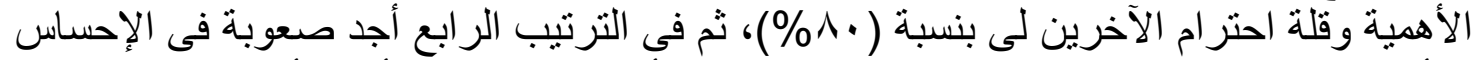

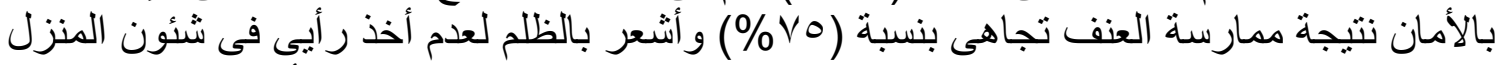

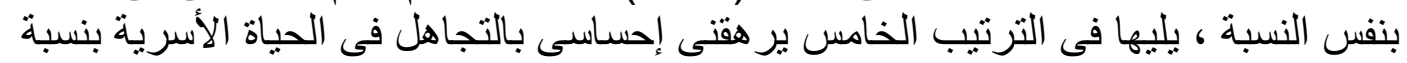

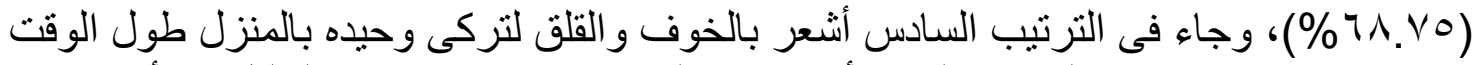

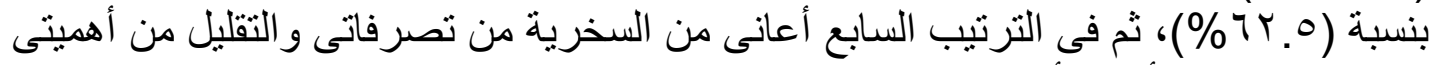

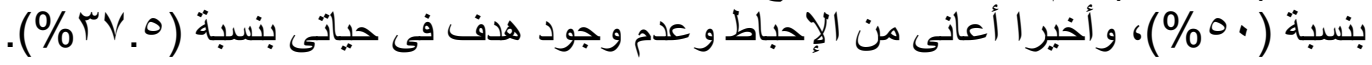

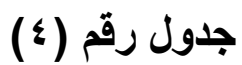

\begin{tabular}{|c|c|c|c|c|}
\hline التر تب & التإس & التك لا. & ; & \\
\hline . & ألمسب & ודה & الحبرة & r \\
\hline$r$ & $\% \wedge \vee . \diamond$ & V. & يعمل على تقييا حريتى الثخصية بإستمرار & 1 \\
\hline $\mathrm{V}$ & $\% 07.40$ & $\leqslant 0$ & يسعى جاهدا على عزلى عن الأقارب والجيران & r \\
\hline$\Lambda$ & $\% r v .0$ & $r \cdot$ & يقوم بمراقبة كل تصرفاتى & $r$ \\
\hline 9 & $\%$ Yo & $r \cdot$ & يمنعنى من المشاركة فى المناسبات الإجتماعية & $\varepsilon$ \\
\hline 7 & $\%$ \% Y.0 & 0 . & أعانى من الخروج للعمل وتكوين شخصيتى & $\bullet$ \\
\hline 1 & $\%: 1 \ldots$ & $\Lambda$. & يعارض أى نشاط يظهر قدراتى & 7 \\
\hline$r$ & $\% 9$ Y.V0 & vo & يتعدد تقليل مكانتى الثخصية أمام أبنائى وأمام الآخرين & $\mathrm{V}$ \\
\hline$\bullet$ & $\% \vee 0$ & 7. & أعانى من مشكلة التهديد بالطلاق بشكل متكرر من زوجى & $\Lambda$ \\
\hline$\varepsilon$ & $\% \wedge 1 . Y 0$ & 70 & أتعرض للحرمان من الأمان والعلاقة السكنيه من قبل زوجى & 9 \\
\hline
\end{tabular}

يوضح الجدول السابق أن: المشكلات الاجتماعية للنساء المعنفات أسريا تتمثل بالترتيب كالآتى: فى الترتيب الأول يعارض أى أى التى

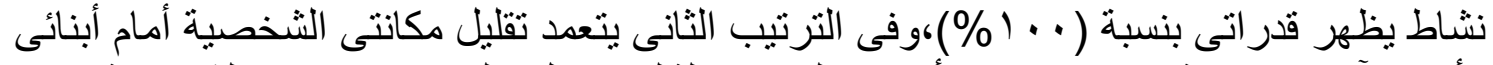

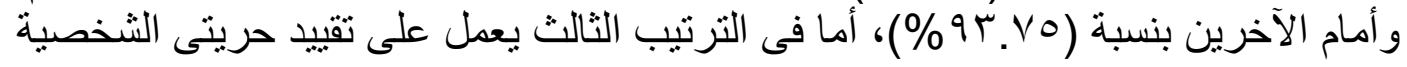




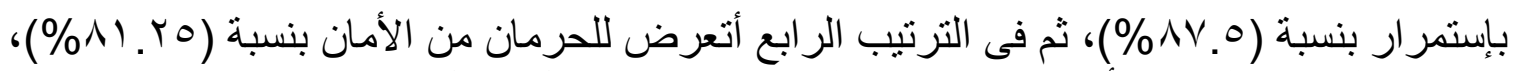

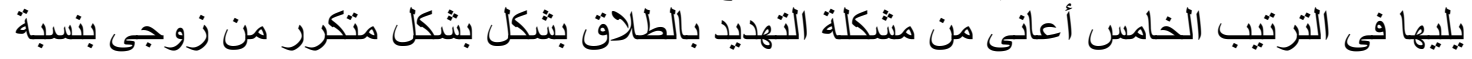

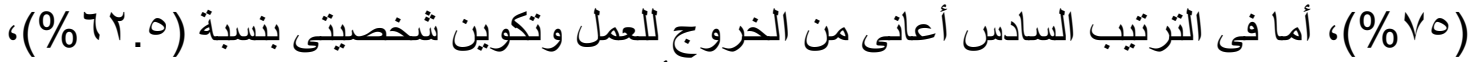

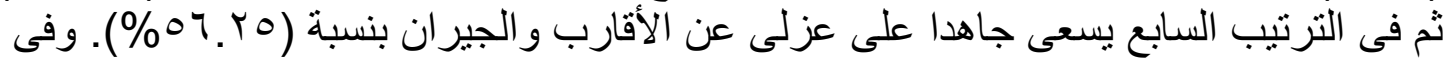

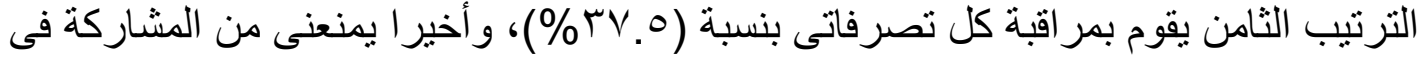

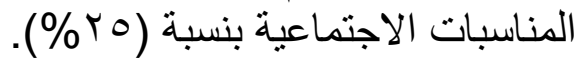

جدول رقم (ن)

يوضح المشكلات الصحية للنساء المعنفات أسريا

\begin{tabular}{|c|c|c|c|c|}
\hline الترتيب & النسبة & التكرار & العبارة - مار & م \\
\hline 1 & $\%$ \%r.o & o. & يمتتع عن إحضار الدواء لى أثناء المرض & 1 \\
\hline$r$ & $\% \vee 0$ & 9. & لا يهتم بتوفير أجواء الراحه والهلوء أثناء مرضى & r \\
\hline 1 & $\% 1$ (.. & $\Lambda$. & لا يهتم كثيرا لظروفى فى حالة المرض & $r$ \\
\hline$r$ & $\%$ \% प.vo & vo & يمنغنى من إجراء الفحوصات الطبية اللازمة & $\xi$ \\
\hline 0 & $\% 04 . Y_{0}$ & ¿0 & يبتُع عنى عندما أكون مريضه & o \\
\hline$r$ & $\% \vee 0$ & 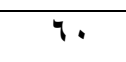 & يمنغنى من زيارة الطبيب & 7 \\
\hline$\varepsilon$ & $\%$ \%४.৩० & 00 & يلومنى عندما أمرض & $\mathrm{v}$ \\
\hline $\mathrm{v}$ & $\% \leqslant r . \vee 0$ & ro & يرغمنى على العمل وأنا مريضه & $\Lambda$ \\
\hline
\end{tabular}

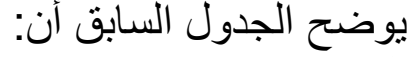

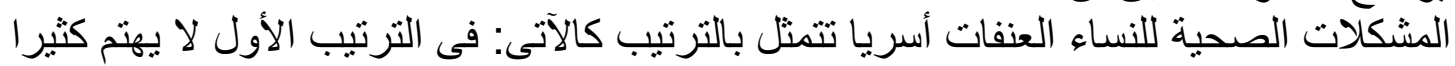

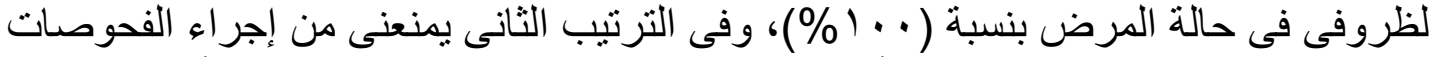

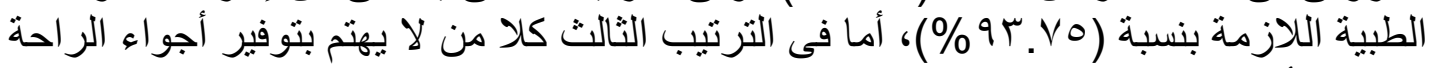

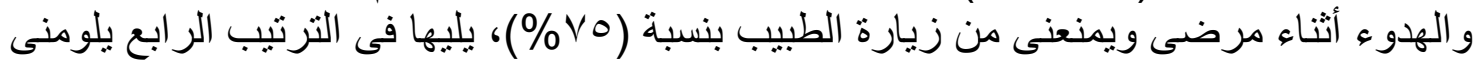

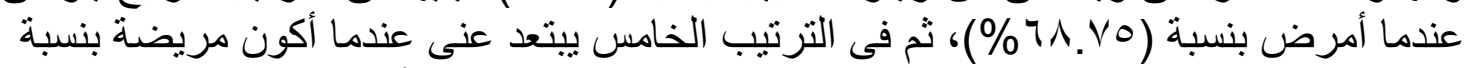

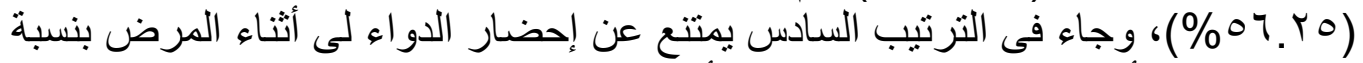

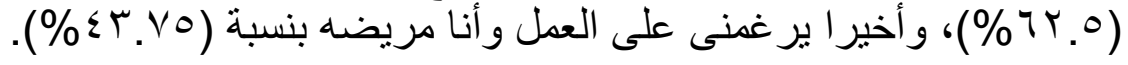




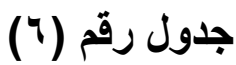

\begin{tabular}{|c|c|c|c|c|}
\hline التر تب & $\ddot{a}$ & d & يوضتح مقترحات للتعامل مع المشكلات التى تواجه النساء المعنفات أسريا & r \\
\hline & & & & \\
\hline 1 & $\% 1 \ldots$ & $\Lambda$. & تنمية وعى الزوجة بحقوقها وواجباتها داخل الأسرة & 1 \\
\hline$\varepsilon$ & $\% \wedge 1 . Y 0$ & 70 & التأكيا على أهمية التسامح وتقبل الآخر ونبذ العنف & $r$ \\
\hline 1 & $\% 1 \ldots$ & $\Lambda$. & توعية الأزواج بكيفية المعاملة السوية للزوجات & $r$ \\
\hline$r$ & $\% 9 r . \vee 0$ & Vo & تأهيل الزوجين فى دورات تأهيل الزواج قبل الزواج & $\varepsilon$ \\
\hline 0 & $\% \vee 0$ & 7. & تزويد المرأة بالإستراتيجيات التى تكفل تسوية الخلافات بطرق سوية بعيدة عن العنف & - \\
\hline 7 & $\% \curlyvee \wedge . \vee \bullet$ & 00 & تكثيف الحملات والندوات للبعد عن هذا السلوك & 7 \\
\hline $\mathrm{V}$ & \%ฯY.O & 0 . & زيادة عدد المؤسسات فى مجال رعاية الأسرة وحل مشكلاتها & $\mathrm{V}$ \\
\hline$r$ & $\% \wedge \vee . \bullet$ & $\mathrm{ve}$ & نشر الوعى الدينى بكيفية معاملة الزوجة وحقوقها & $\Lambda$ \\
\hline r & $\% 9$ Y.V० & Vo & إصدار تشريعات لمناهضة العنف ضد المرأة & 9 \\
\hline$\varepsilon$ & $\% \wedge 1 . Y_{0}$ & 70 & تأسيس مراكز حماية تهتم بقضايا المرأة ومسناعلتها فى كل محافظة & 1. \\
\hline $\mathrm{V}$ & \%ฯY.० & 0. & محاولة التوافق بين الزوجين وتتليب المصلحة اللأسرية & 11 \\
\hline$\Lambda$ & $\% \bullet ૫ . Y \bullet$ & \&0 & لجوء الزوجة إلى الأهل أو القضاء والجهات ذات الصلة & ir \\
\hline
\end{tabular}

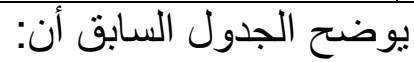

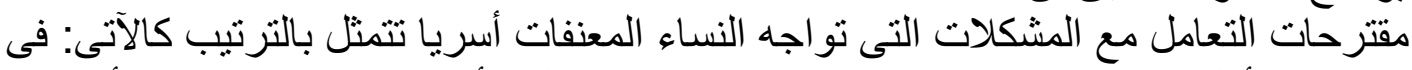

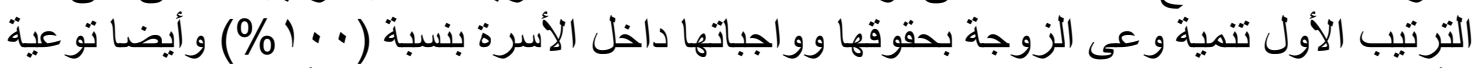

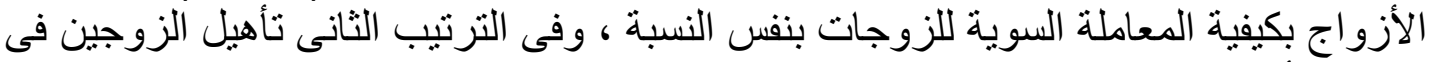

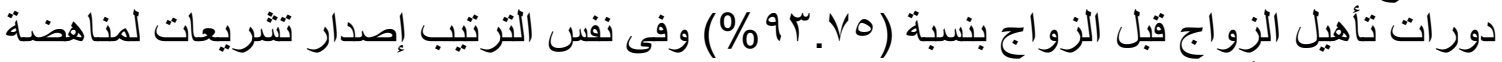

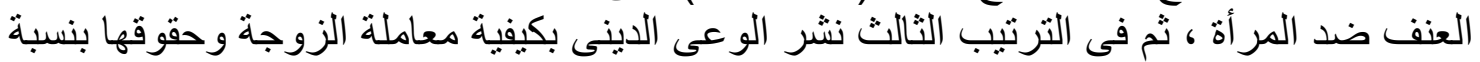

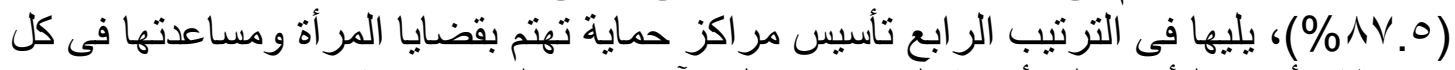

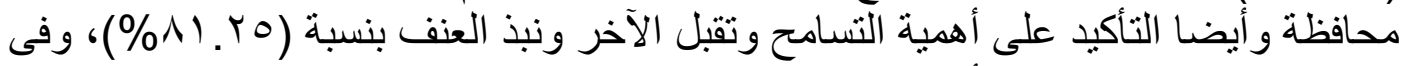

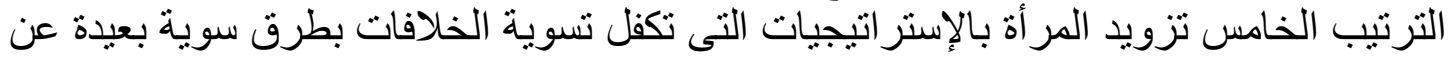

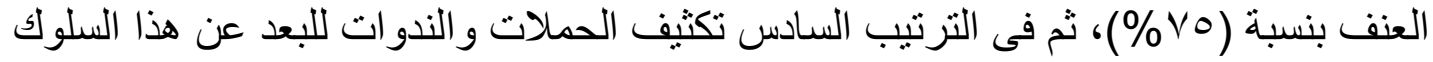

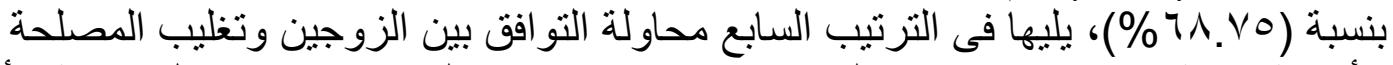

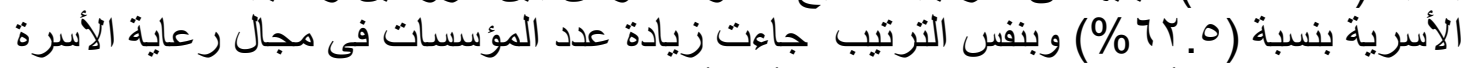

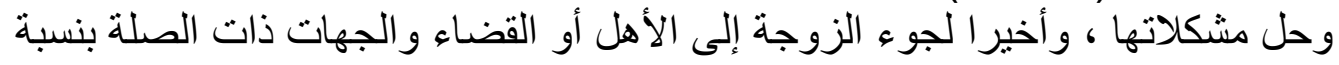
. (\%०\%.

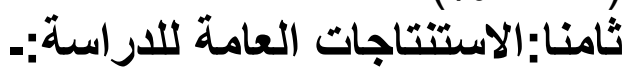

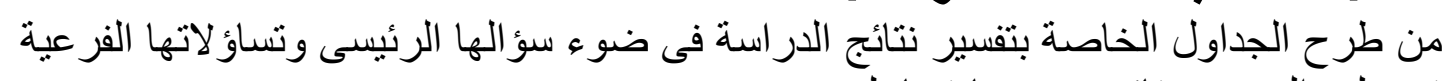
توصلت إلى عدة نتائج، نبرز ها فيما يلى: 


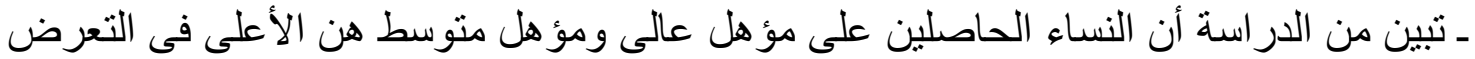

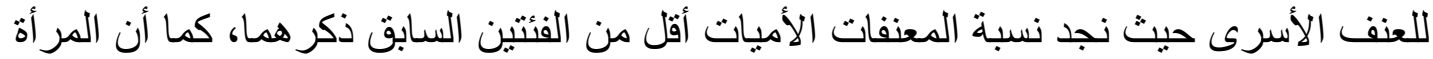

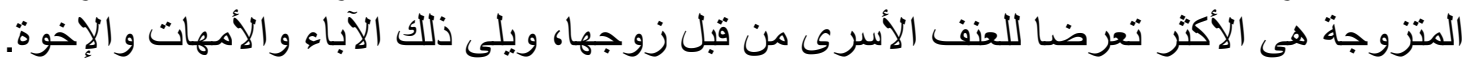

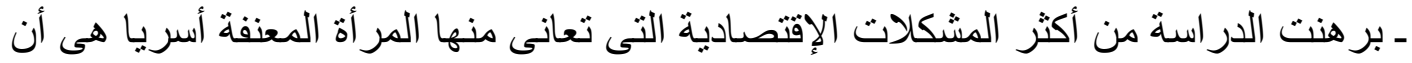
الزوج غير متعاون فى تدبير نفقات الحياه المعيشيها. ـ أوضحت الدر اسة أن أكثر المشكلات النفسية التى تعانى منها المرانية أنهات المعنفة أسريا أنها تفكر دائما

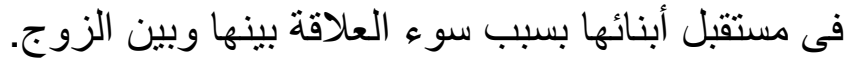

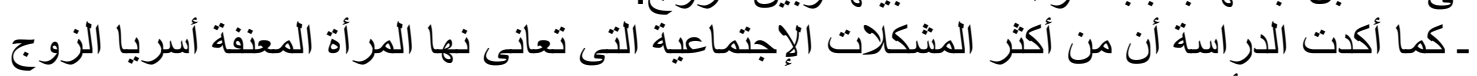

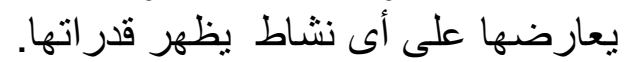
ـ و أبرزت أيضا أن أكثر المشكلات الصحية التى تعانى منها المر أة المعنفة أسريا أن الزوج لايهتم

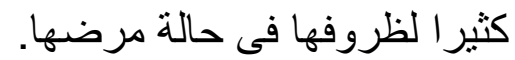

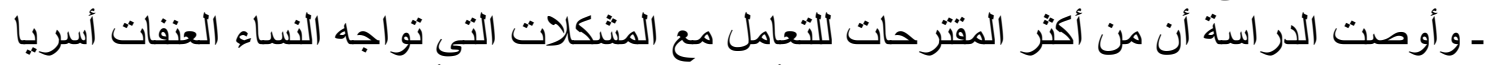

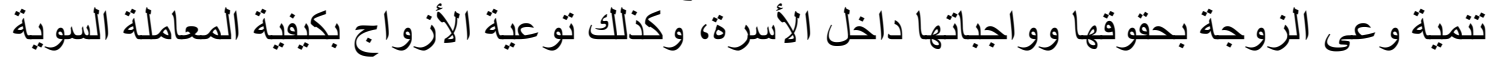

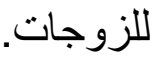

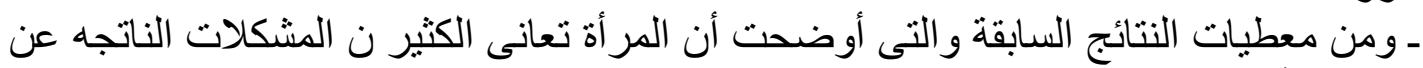

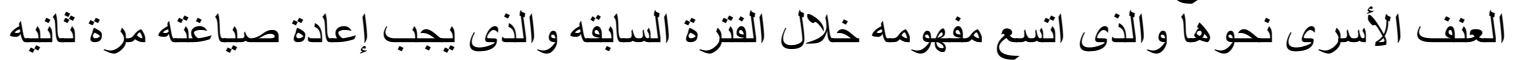

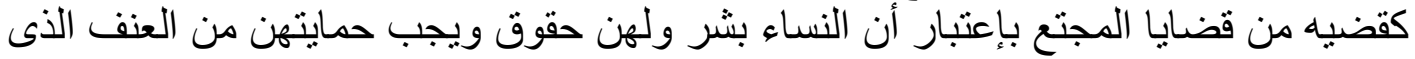

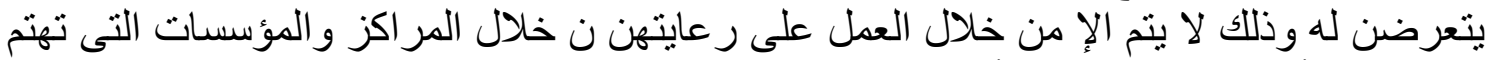

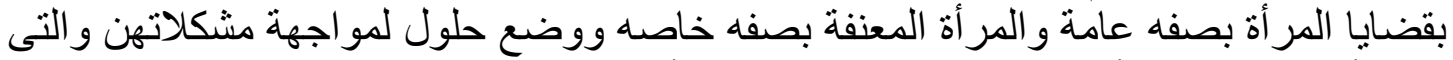

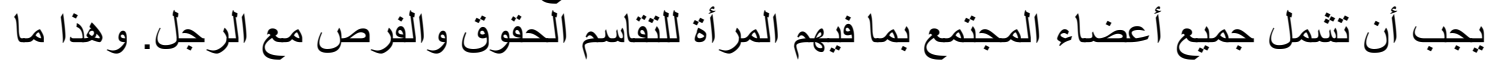

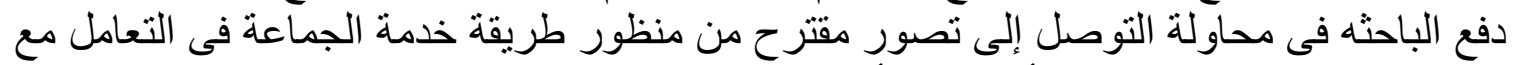
المشكلات النى تعانى منها المر أة المعنفة أسريا.

\section{تاسعا: تصور مقترح من منظور خدمة الجماعة فى التعامل مع المشكلات التى تعانى

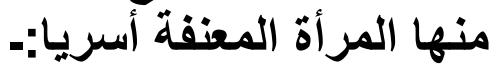

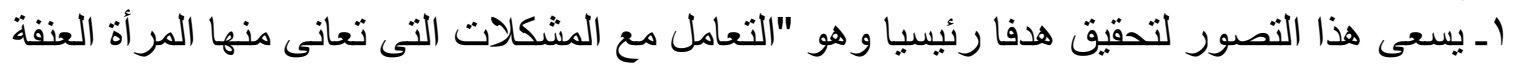

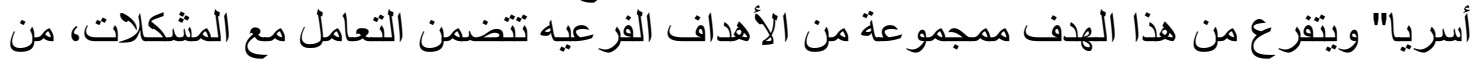

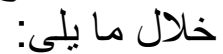
أـ كيف تقوم خدمة الجماعة كطريقة فى التعامل مع المشكلات الإقتصادية التى تعانى منها المر أة المعنفة أسريا. ب ـ كيف تقوم خدمة الجماعة كطريقة فى التعامل مع المشكلات النفسية التى تعانى منها المر أة المعنفة أسريا. ج ـ كيف تقوم خدمة الجماعة كطريقة فى التعامل مع المشكلات الإجتماعية التى تعانى منها المر أة المعنفة أسريا. دـ كيف تقوم خدمة الجماعة كطريقة فى التعامل مع المشكلات الصحية التى تعانى منها المر أة المعنفة أسريا. 
هـ ـ تحديد أهم المتطلبات التى تؤدى إلى نجاح التصور فى التعامل مع المشكلات التى تعانى منها

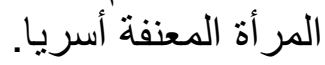
r ـ الموجهات العلمية التى يعتمد عليها التصنية التصور:-

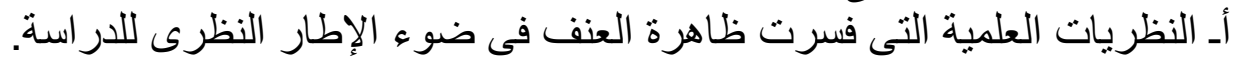

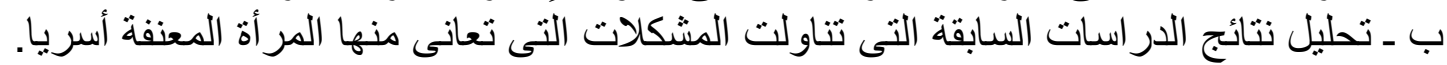

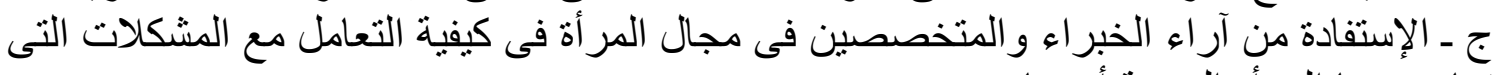
تعانى منها المر أة المعنفة أسريا.

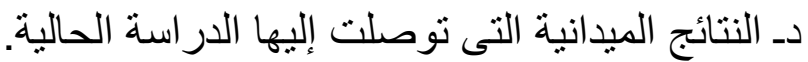

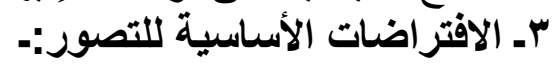

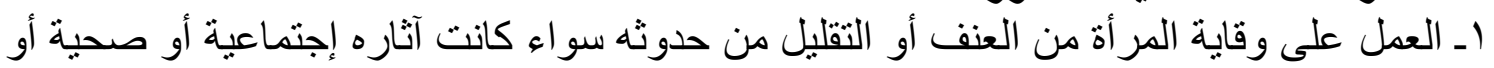

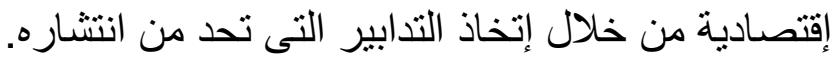

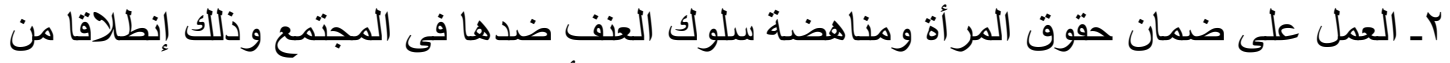

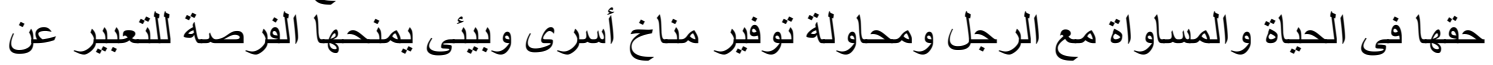
إتجاهاتها و انفعالاتها بطريقة إيجابية.

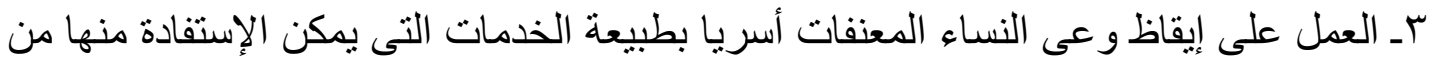

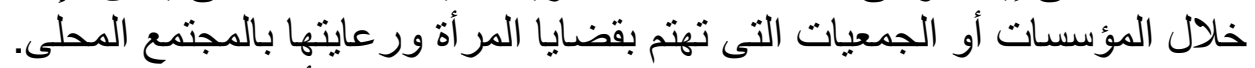
عـ القيام بتهيئة الظروف المناسبة التى تساعد النساء المعنفات أسريا على استثمار قدر اتهن

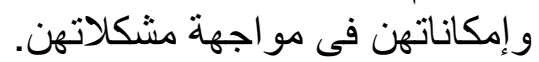

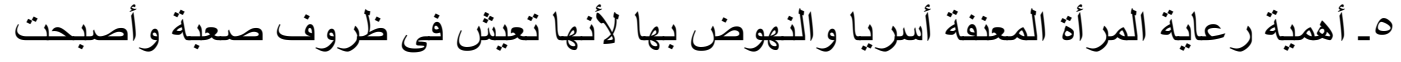
مساعدتها ضرورة تقتضيها ظروفها فى ظل التغيرات الإيجابية والسلبية التى يمر بها المجتمع

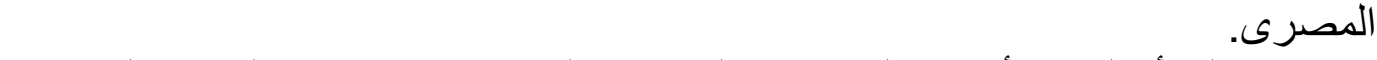

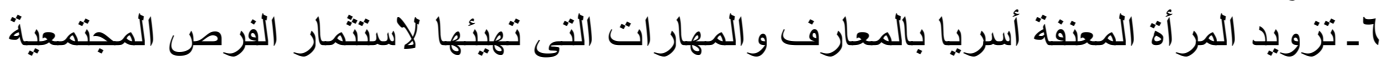

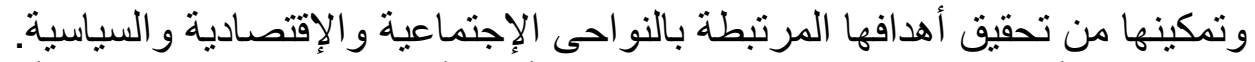

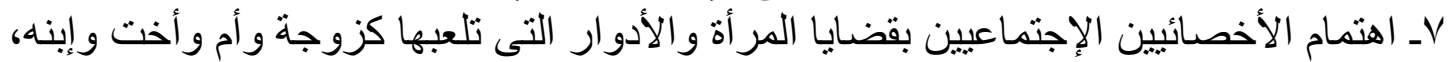
وكذللك المشكلات التى تعانيها في المنزل التئل و العمل و المجتمع ككل.

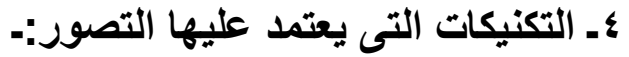

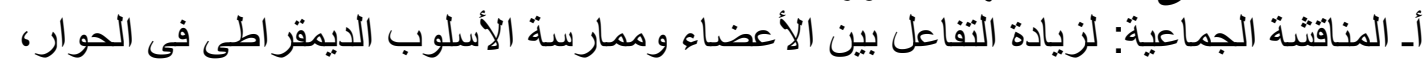

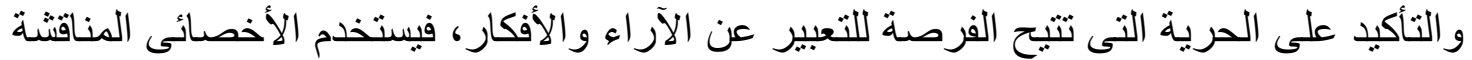

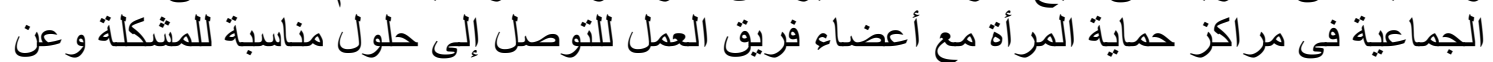

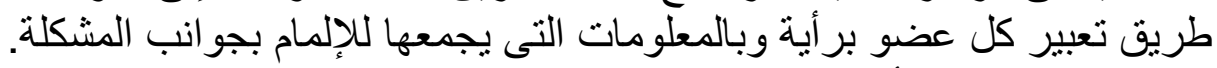

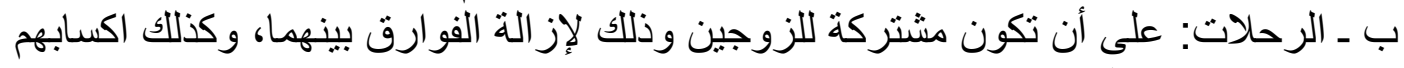

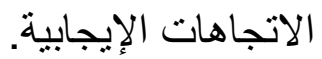
ج ـ الندوات: لتنمية وعى المر أة بحقوقها و الإهتمام بمشكلاتها.

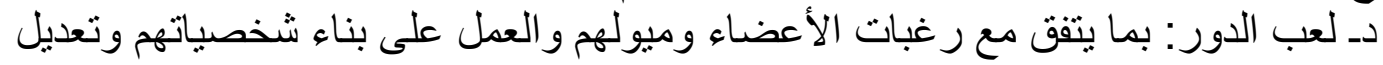

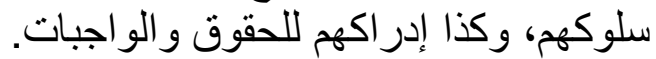
هـ ـ الزيار ات: بين المؤسسات و الجمعيات التى تهتم وتدعم الوعى بحقوق المر الته أة ومناقثة القضايا

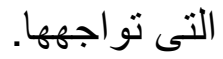
وـ الملاحظة: لمشاهدة كيف تتعامل المر أة مع زملاءها ومر اقبة إنفعالاتها مطابقة للحالة الظاهرية أم

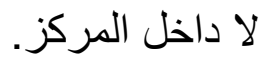




\section{هـ الاستراتيجيات التى يستخدمها التصور:-}

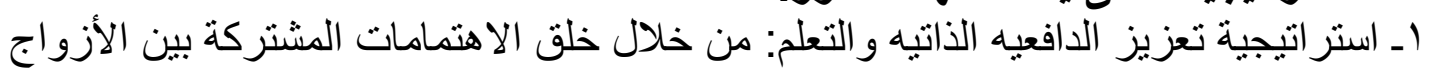

وزوجاتهم.

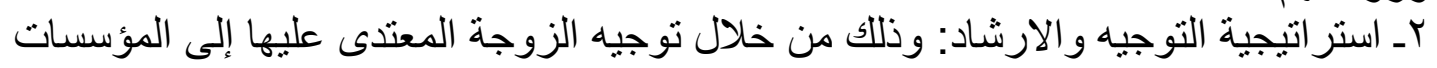

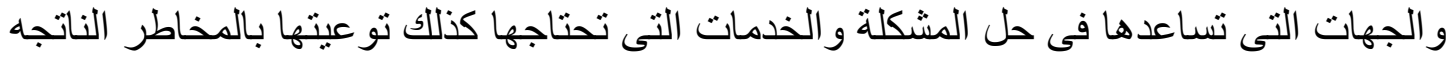
عن تعرضها للعنف وكيفية الوقاية منها تهنه rـ استر اتيجية تحقيق العدالة: وتفعيل المساو الة بين الرجئ الرجل و والمر أة لضمان حريتها وتحقيق مبدأ تكافؤ الفرص فى الحقوق و الواجبات.

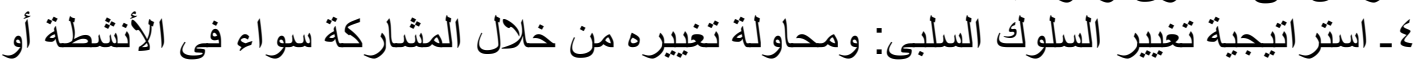
الندو ات وما يرتبط بذلك من تكنيكات وتعديل الاتجاهات السلبية وزيادة الحافز لإدر الك الوعى، الوكي،

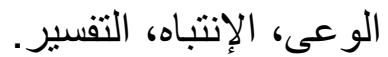

\section{آـ المهارات التى يستخدمها أخصائى الجماعة فى إطار التصور:-}

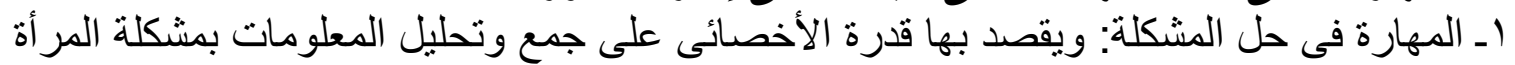

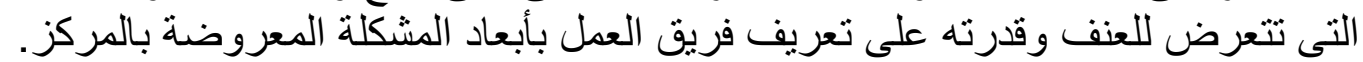

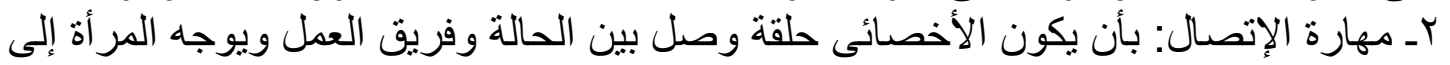

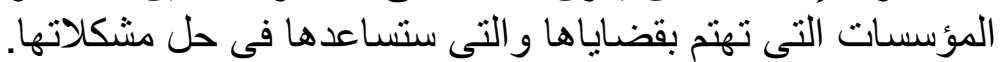

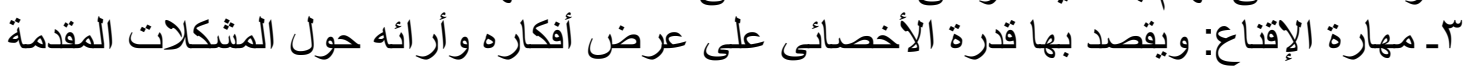

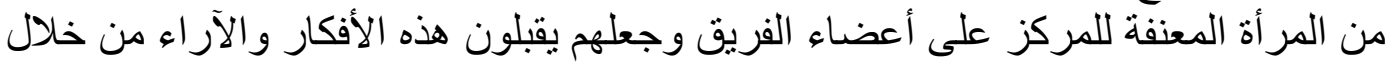

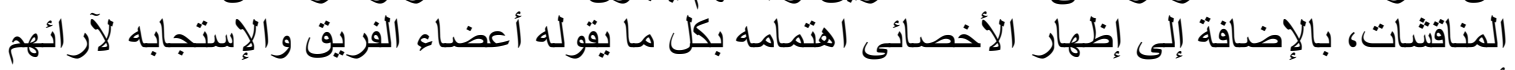

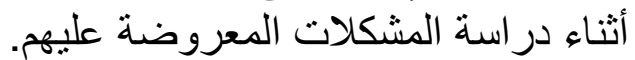

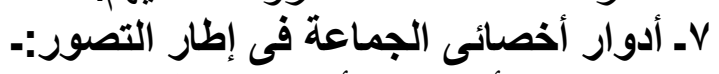

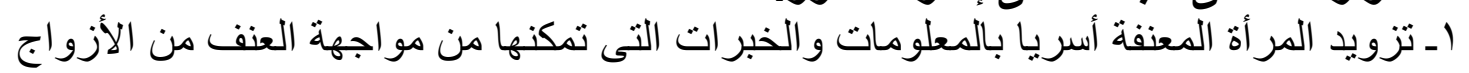
و وكيفية التعامل معهم.

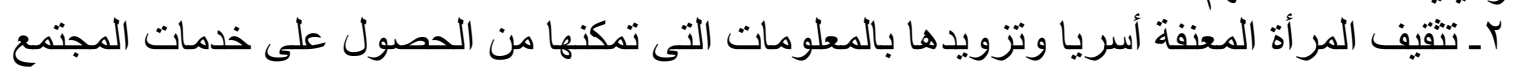

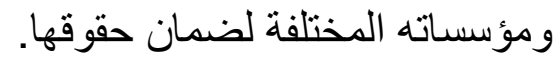
بـ الاستفاده من طاقات النساء المعنفات أسريا اللذان يملكن الخبره و المهارة فى عمل معين للتطوع

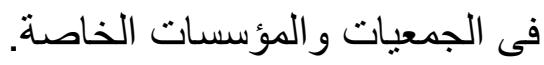
عـ عقد الندو ات و المناقتنات و المؤتمر ات لمناقثة مشكلات النساء المعنفات أسريا وكيفية التعامل معها أو علاجها.

هـ إعداد بر امج تدرييية لتأهيل و إعداد أخصائيين متخصصيبين يعملون فى هذا المجال.

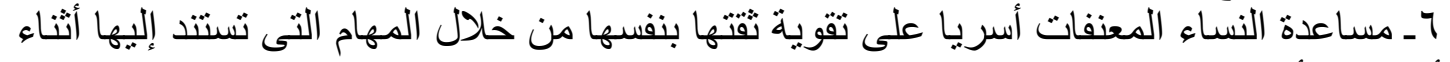

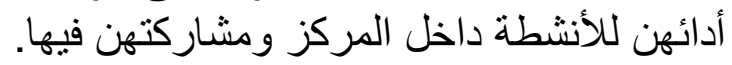

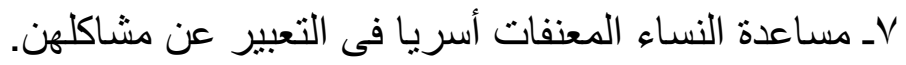
Aـ التنسيق بين المؤسسات و الجمعيات العاملة في مجال النعات النساء المعنفات أسريا من حيث الخدمات

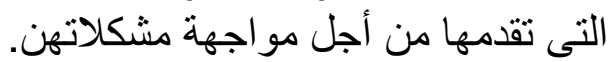

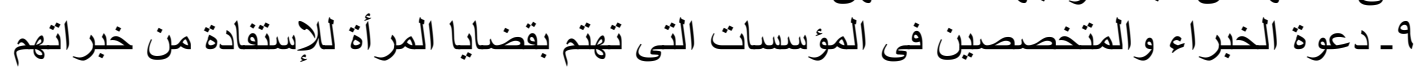

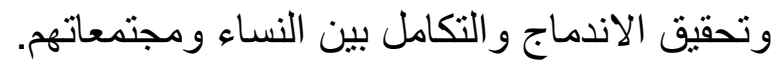
• ـ الدعوة إلى إصدار التشريعات الاجتماعية الخاصة باهية بالحفاظ على حقوق النساء المعنفات أسريا

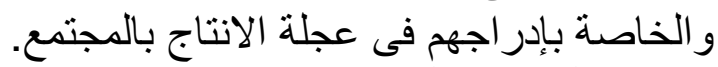
1 ا ـ العمل على حل المشكلات التى تو اجه فريق العثئ العمل بمؤسسات أو جمعيات رعاية المر أة المعنفة. 
r ا ـ تكثيف الدور التنموى و التوعية من خلال الإعلام ووسائل التو اصل الاجتماعى لتوضيح مشكلة

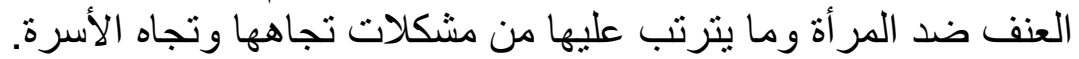

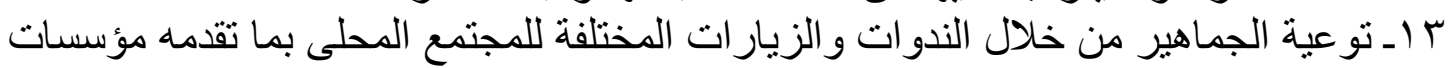

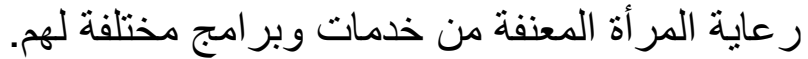
ـ ا ـ تنظيم الندوات و المحاضر ات المتعلة القعة بالجانب الدينى ونشر التو عية الدينية بين الأسر بخطورة

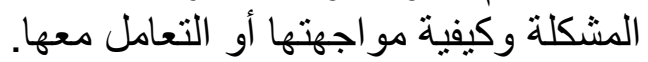
1ـ متطلبات نجاح التصور المقترح:-

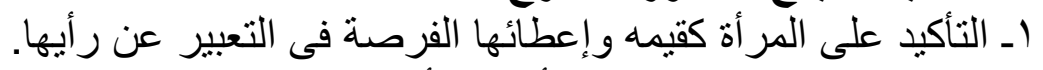

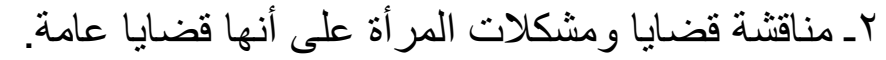

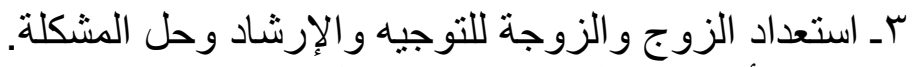

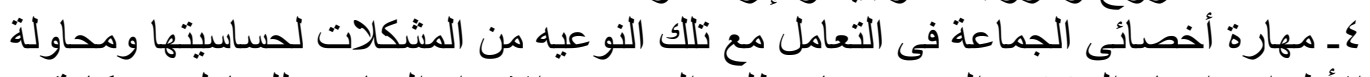

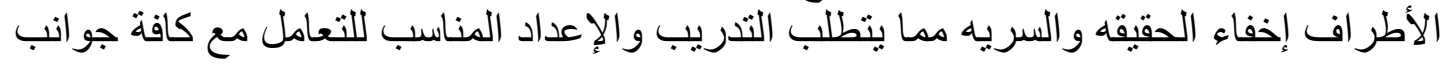

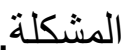
هـ تنمية المهار ات و القدرات اللازمه للمر أة والتى تؤكد تو اجدها بالمجتمع جنبا إلى جنب مع الرجل

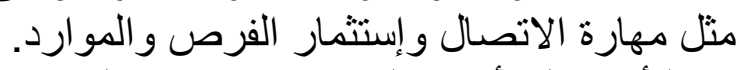

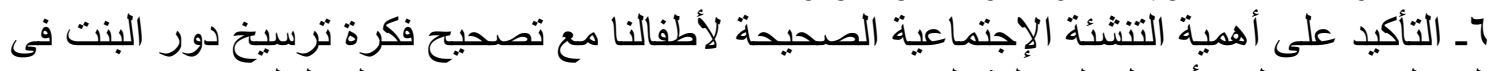

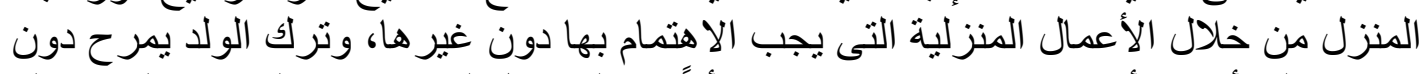
تربيته على أن ينشأ تنشئه صحيحه حتى يكون ألباً في المستقبل لله حقوق و عليه مسئوليات مثلك مثل الفتاه. Vـ التأكيد على العلاقات الانسانية ، وأن كل إنسان يؤثر ويتأثر بالآخرين.

\section{أولا: المراجع المستخدمه:-}

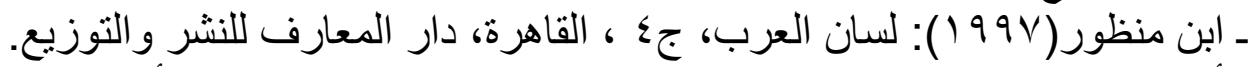

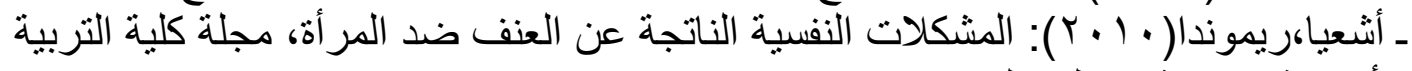

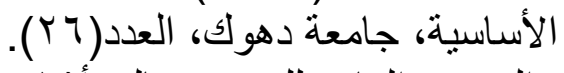

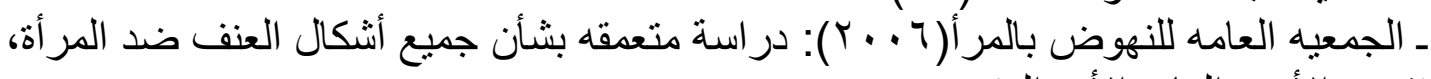

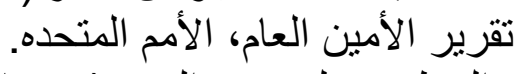

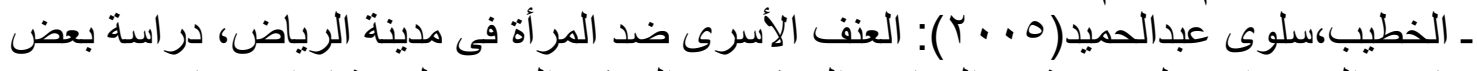

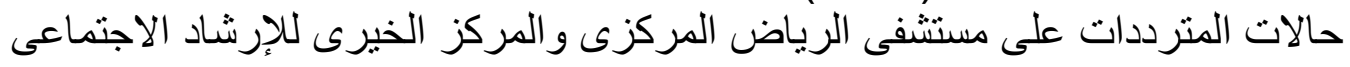


و الاستشار ات الأسريه، مجلة مركز بحوث مركز الدر اسات الجامعية للبنات، ع( • (ب).

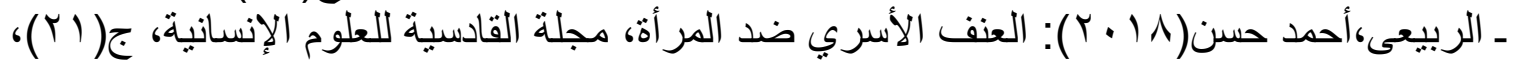

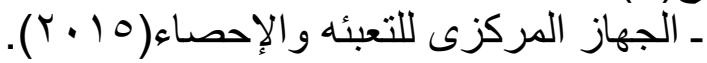

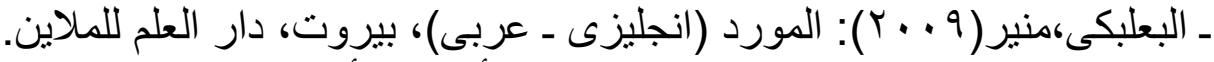

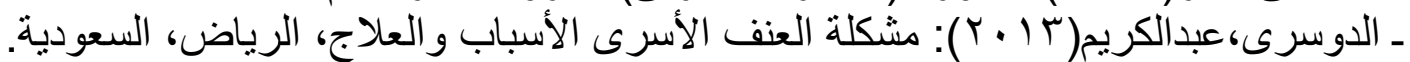

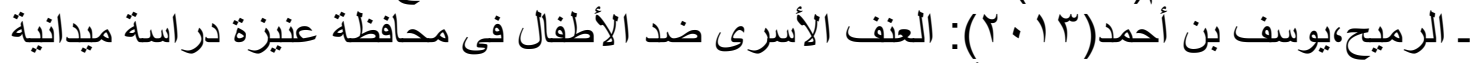

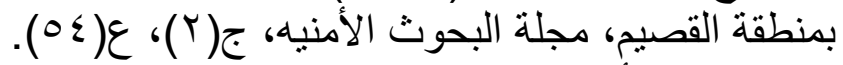

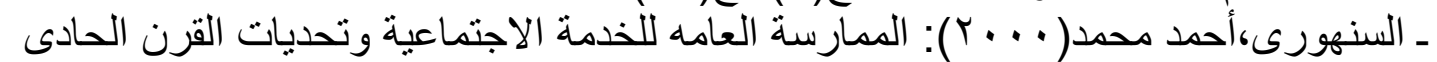
و العشرين، طب، القاهرة، دار النهضة العربة العربية.

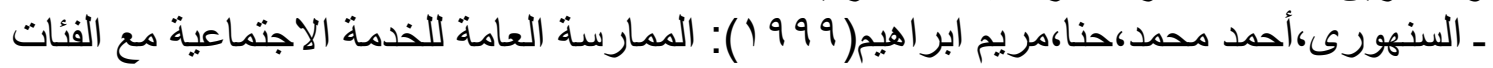

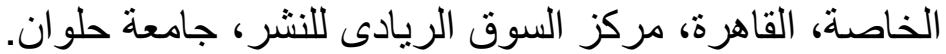

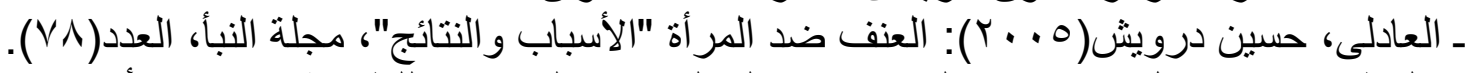

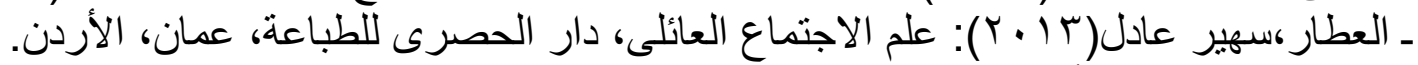

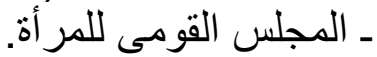

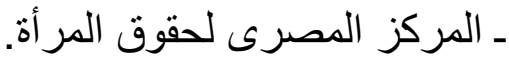

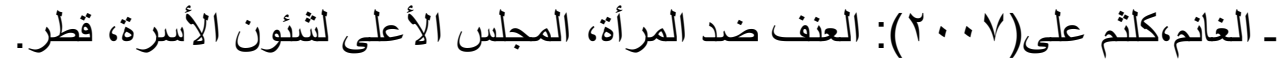

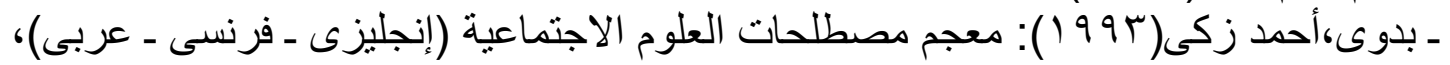

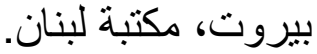

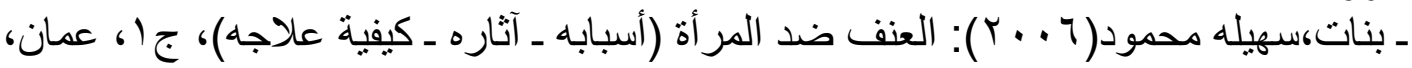

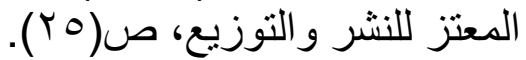

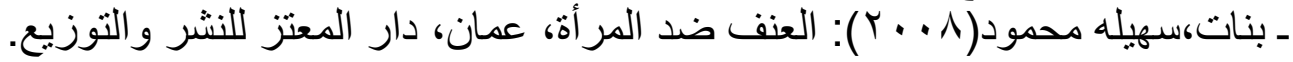

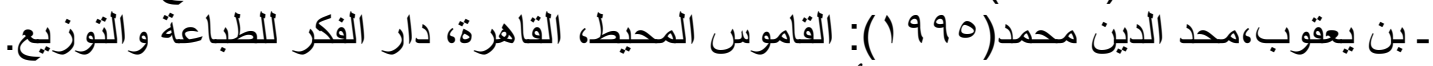

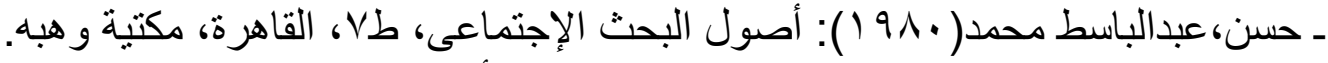

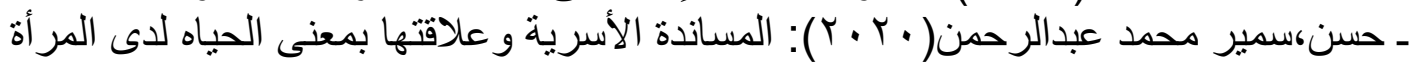

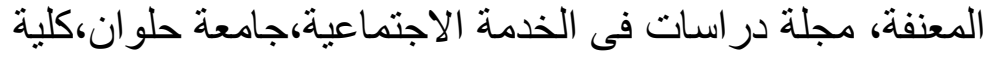

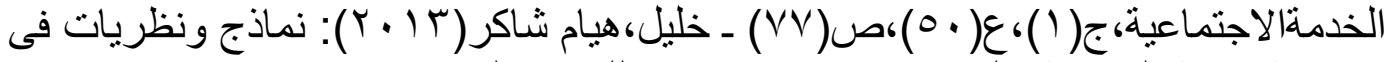
ممارسة خدمة الجماعة، القاهرة، دار نور الإيمان للنشر والتوزيع.

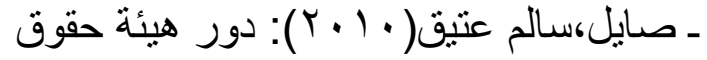

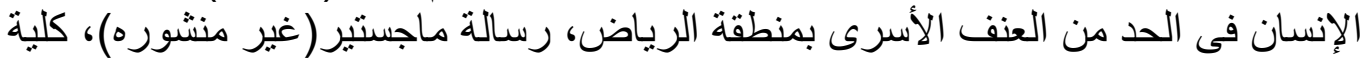

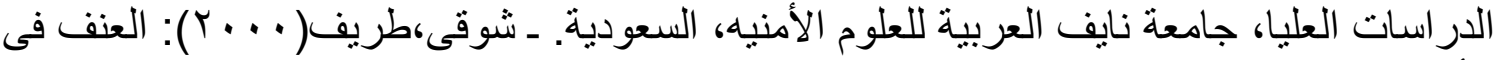

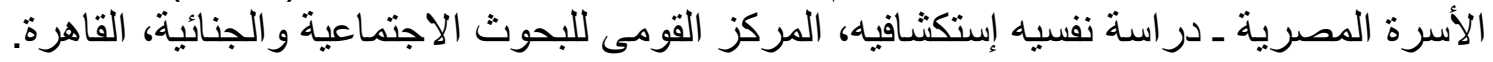

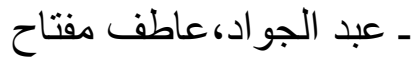

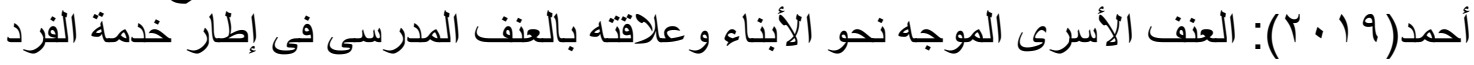

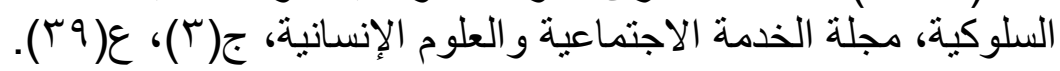
ـ عبدالو هاب،ليلي( ع 99 (1): العنف

الأسرى (الجريمة و العنف ضد المرأة)، بيروت، لبنان، دار المدى للثقافة والنشر.

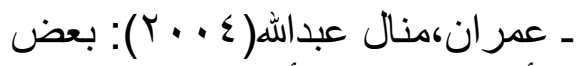

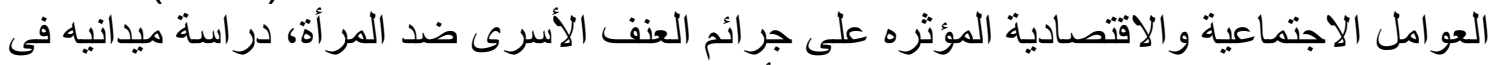
القاهرة، رسالة دكتور اه (غير منشوره)، كلية الأداب، جامعة عين شئر الأنس. 


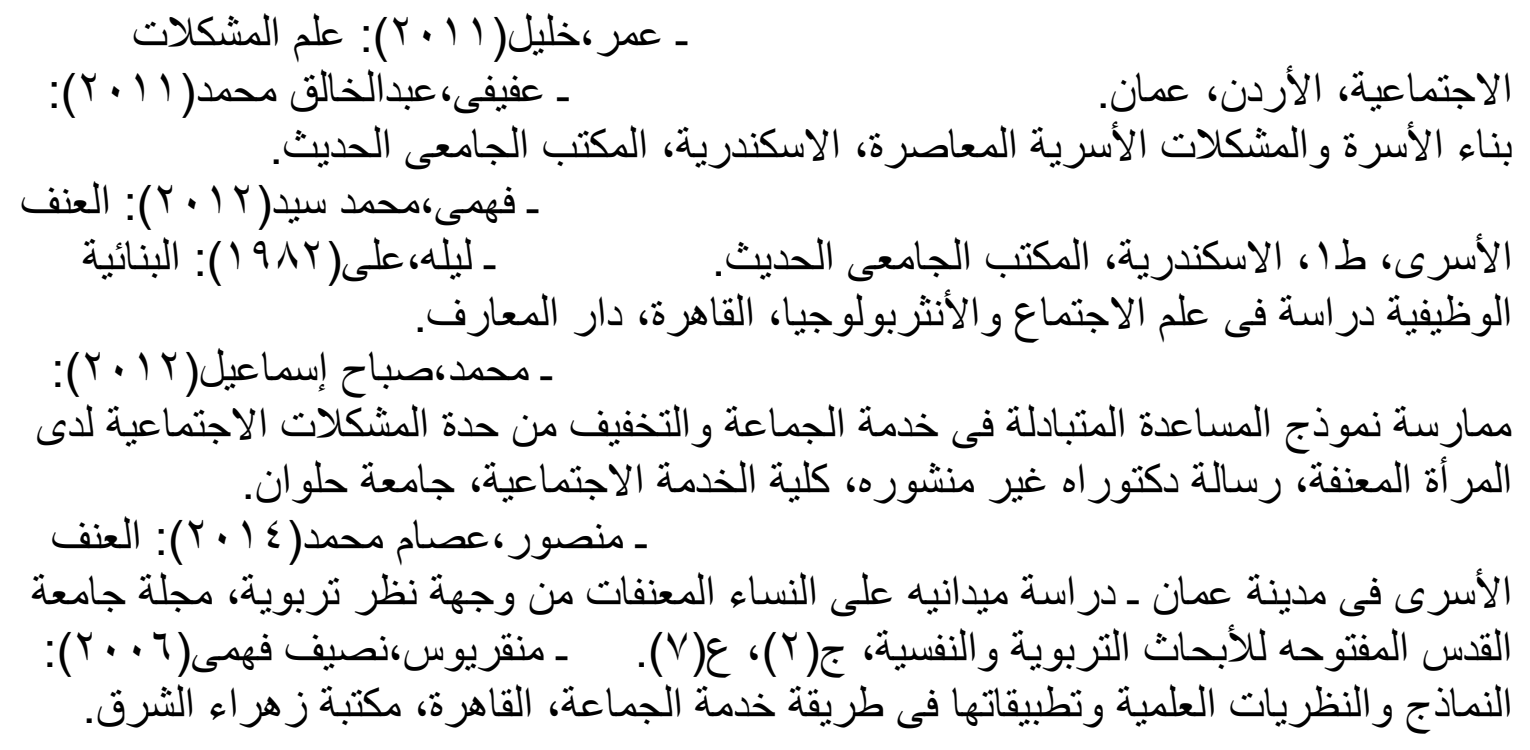

ثانيا: المراجع الأجنبية

- AgnewF. \& Huguleys(1988).,Adolescence violence Toward parents: An Examination of extent correlates and causes if parents assult,A.S.A.

- Kaloudi, E., M. 1.Psarra, Gkalemi, J.douzenis,\& a.douzenis(2017).Violence in afamily setting, ENCE PHALOS Journal 54,PP.28-32.

- Rivera C. \& switzerk (1976), violence, N.J., Hayden Book company inc.

- Romito, P. (2008). Adeafening silence: Hidden violence against women and children. Policy press PP.46-48.

- Subramaniam, J .\& Zulkarnain, A.(2017). Behavioural problems of children Exposed to Domestic violence, procedia social and Behavioral sciences Journal, 91, PP. 201-207.

- Veram, Ravik (2003): "wife beating and the link with poor sexual health and risk behavior among men in India" Journal of comparative family studies spcial issue vilonecealgaints wimen the family canda. $P$ 65. 